Ankara University Faculty of Educational Sciences Journal of Special Education

2022, 23(3), 699-720
REVIEW

Recieved Date: 07.01.20

Accepted Date: 07.09.21

Online First: 02.11 .21

\title{
Classroom Management: Significance in Inclusive Education, Current Problems and Proposed Solutions
}

\author{
Nevin Güner-Yıldız
}

\author{
Hasan Köse ${ }^{i D} 2$
}

Esra Akın 3

\begin{abstract}
Introduction: It is a known fact that teachers' knowledge and use of effective classroom management (CM) strategies has a positive impact on their professional achievement and their students' learning outcomes. Effective strategies that teachers can use are presented in various scientific studies. However, these strategies are not used sufficiently in practice for various reasons, and therefore, in many classrooms, controlling students' problem behavior, focusing students on activities, and maintaining effective education is not yet a task that teachers achieved adequately. Besides, educational settings become more inclusive day by day and increased student diversity add to the complexity of problems encountered in CM. In the light of literature, this study aims to identify the problems encountered about CM by today's teachers along with the causes of these problems and to present tools that can be used to solve these problems.

Discussion: With this purpose, the study examined the content of the "2023 Education Vision" prepared by the Ministry of National Education (MoNE) of Turkey as a short-term guide to solve the problems in the system of education in regards to classroom management. The study also presents some recommendations to policymakers about the changes planned in teacher training and professional development programs to solve problems related to $\mathrm{CM}$.
\end{abstract}

Keywords: Classroom management, teacher training, inclusive education, 2023 education vision, simulation, coaching.

To cite: Güner-Yıldız, N., Köse, H., \& Akın, E. (2022). Classroom management: Significance in inclusive education, current problems and proposed solutions. Ankara University Faculty of Educational Sciences Journal of Special Education, 23(3), 699-720. https://doi.org/10.21565/ozelegitimdergisi.856085

${ }^{1}$ Corresponding Author: Assoc. Prof., Eskişehir Osmangazi University, E-mail: antreh@gmail.com, https://orcid.org/00000002-9135-6429

${ }^{2}$ Teacher, Ministry of National Education, E-mail: hsnkose@ hotmail.com, https://orcid.org/0000-0002-0923-3711

${ }^{3}$ Res. Assist., Eskişehir Osmangazi University, E-mail: esraak762@gmail.com, https://orcid.org/0000-0002-7414-1207 


\section{Introduction}

The term "classroom management" (CM) sometimes brings to mind a mechanical, authoritarian management style that maximizes control and obedience and also individuals with this mindset may believe that classroom management solely consists of controlling students. However, CM is a more complex and versatile effort to manage student behavior and the classroom as a group than simply establishing rules, rewards, and sanctions or consequences (Evertson \& Weinstein, 2013). Evertson and Weinstein (2013) define CM generally as the steps taken by teachers to create an environment that supports and facilitates both academic and socialemotional development. Evidence-based strategies that can be used for effective CM can be grouped under five headings. These; (a) reducing stimuli that may cause distractions by making physical arrangements in the educational environment, (b) using teaching strategies that support the active participation of students, (c) teaching classroom rules, following them consistently, and providing feedback to students when necessary, (d) validating students' positive behaviors consistently; and (e) responding consistently to problem behavior (Simonsen et al., 2008). With effective CM strategies, teachers can improve students' success, level of participation in activities, and positive peer relationships, also reduce problem behaviors that are off-task, destructive, and disturb the teacher and other students in the classroom (Gaias et al., 2019). Teachers with satisfactory expertise in CM can maximize learning and minimize disruptions and therefore offer an effective learning environment. Besides, effective CM strategies positively affect teachers' mental wellbeing and help prevent occupational stress and burnout (Weber et al., 2018). In this respect, effective CM strategies should be regarded as the most valuable tool for teachers, and teachers' professional development in this field should be supported (Korb et al., 2016).

\section{Classroom Management and Inclusive Education}

Inclusive education practices, which are shortly defined as enabling schools to serve all children, especially those with special education needs (United Nations Educational, Scientific and Cultural Organization [UNESCO], 1994), are becoming increasingly widespread throughout the world (Emmer \& Stough, 2001). Classrooms with inclusive education practices have increased student diversity and hence teachers are required to create and utilize solutions that match the different learning needs of their students (Carneiro et al., 2015). However, it is emphasized in the literature that teachers working in inclusive classrooms generally feel unprepared to teach special needs students and have negative attitudes towards inclusion (Civitillo et al., 2016; Hemmings \& Woodcock, 2011; Sadioğlu et al., 2013). In addition, researches reveal that teachers' knowledge of inclusion is insufficient (Sucuoğlu et al., 2014; Thaver \& Lim, 2014) and that teachers do not want to accept these children in their classes because of complaining about problem behaviors of children with special needs (Daniels, 1998; Mitchem \& Benyo, 2000). This attitude towards inclusive education are known to be related to teachers' selfefficacy perceptions. Low self-efficacy perceptions reflect teachers' lack of confidence towards their teaching skills and especially in regards to CM skills (Jung, 2007). Teachers' knowledge and use of effective CM strategies will increase achievement in inclusive education classrooms. CM strategies that include preventive strategies, support and communication strategies, general intervention strategies, and motivation strategies will extensively contribute to the learning outcomes of every student (Carneiro et al., 2015). A well-managed classroom supports the academic and social development of all children with or without special needs, helps reduce problem behaviors, and prevents the majority of potential negative behaviors. Also, when teachers differentiate the CM strategies, they use according to the needs of students, they will be able to establish a more efficient interaction with children that display different ability levels (Sucuoğlu et al., 2017).

\section{Ongoing Problems in Classroom Management}

Until the 1950s, there was not much development in the field of CM (Brophy, 2013), a significant source of anxiety for all teachers, especially those who are new to the profession (Dinsmore, 2003; Veenman, 1984). The relationship between teacher behavior and student behavior was first presented by Jacop S. Kounin in 1970 with a study called "Discipline and Group Management in Classrooms". In this pioneering study, Kounin called attention to preventive methods and demonstrated the basic principles of CM such as "with-it-ness", overlapping, momentum, smoothness, group management, and use of teaching techniques (Güner, 2011). While effective CM strategies for teachers have been scientifically identified, CM is still one of the areas that generate the highest level of anxiety for teacher candidates and teachers who have just started their careers (Eisenman et al., 2015). Teacher candidates generally consider teacher training, especially the CM training they receive, as inadequate for their future professional life (Flower et al., 2017). A series of studies conducted in this field also confirm that the main area where new teachers feel inadequate is CM (Dinsmore, 2003; Kher et al., 2000; Zuckerman, 2007). Experienced teachers are also found to express similar feelings in regards to this issue (Tripp \& Seals, 2017). 
Studies conducted in this field demonstrate that most teachers view CM as a very important course but state that find the CM training received in the university to be highly inadequate (Eisenman et al., 2015).

Another point worth discussing here is whether the teachers who feel competent in CM strategies are really successful in this regard. The study conducted by Poulou et al. (2019) examined the relationship between teachers' self-efficacy perceptions about CM and their level of using effective CM strategies. The research results pointed to significant differences between the self-efficacy perceptions reported by the teachers and the scores given by the observers. The teachers who participated in the study expressed that they felt efficient while using CM strategies, however, it was observed that teachers would not or could not use these strategies in real classroom situations. This study exemplifies the fact that even when teachers find themselves competent in CM, the actual situation may be quite different.

Gage et al. (2018) examined the relationship between teachers' rates of applying CM skills in classrooms and their students' learning outcomes by observing 1.242 teacher-student pair samples from 65 primary schools in various school districts. The study results demonstrated that students' participation level was significantly low in the classrooms taught by teachers who could not effectively use CM strategies (20\%). The ratio of teachers who could use effective CM strategies was found to be only 18\%. Based on these results, it can be argued that a significant number of teachers do not know or practice effective CM strategies.

A review of the studies on inclusive education practices points to problems related to CM in today's general education classrooms where student diversity is increasing day by day. Gök (2013) conducted a study "to identify the CM challenges encountered by classroom teachers working in inclusive education classrooms and the methods used by teachers to cope with these difficulties". The data collected from 10 classroom teachers using qualitative methods was analyzed. The findings demonstrated that participating teachers who had special needs students in their class experienced problems with CM. The participating teachers reported that they did not receive adequate training on $\mathrm{CM}$ or the limited training they received did not work. Babaoğlan and Y1lmaz (2010) conducted a study to determine classroom teachers' training on inclusive practices and their self-efficacy perceptions. All the participants in the study $(n=40)$ reported that they did not take a course on inclusive education in the teacher training program they attended. Only six participants reported that there was relevant content on "inclusion" in the courses they took. On the other hand, all of the participants expressed that they found their knowledge of inclusion to be insufficient.

The increase in the number of immigrant or refugee families is another factor that adds to the increase in student diversity in today's general education classrooms. Kırılmaz and Öntaş (2020) conducted a study to determine the level of classroom teachers' use of inclusive education practices for refugees. The participants of the study consisted of three classroom teachers, five refugee students, and six Turkish students in these teachers' classrooms. The findings of this qualitative study point to the existence of serious problems such as that refugee students do not sufficiently participate in lessons and social environments, teachers cannot diversify the methodstechniques-equipment used in lessons, and the refugee children have school attendance problems. As a result of the research, it was concluded that the social requirements of inclusive education could be partially met. Ünal and Aladağ (2020) examined the opinions of 10 class teachers working in inclusive classrooms in which refugee students were present in Kayseri province about inclusive education practices. Findings of the study revealed that students experienced difficulties such as participation in group activities and expressing themselves due to language problems and that teachers had communication and teaching problems with students whose native language is different. In addition, the authors highlighted the teachers' lack of knowledge and experience with inclusive education. These studies conducted in classes which have refugee students show that increased diversity complicated classroom and behavior management problems. The results of the studies presented in the literature demonstrate that teachers' problems in regards to CM are still current today. For this reason, more effective professional development programs are required to support teachers and teacher candidates in using CM strategies.

\section{Getting Teacher Candidates Ready for Classroom Management: Lack of Practice}

Problems related to $\mathrm{CM}$ which can be an important cause of teacher burnout and job dissatisfaction (Evertson \& Weinstein, 2013) are experienced daily in most classes. Some teachers constantly demand additional practice support, especially for classroom behavioral interventions (Ali et al., 2018) probably due to limited training on this subject during their teacher training programs or the ineffectiveness of the methods used in CM training (Tripp \& Seals, 2017; Wolff et al., 2020). University-based teacher training programs are often criticized for being too theoretical. Many teacher training programs present their course contents and teaching knowledge and skills in a theoretical manner (Larson et al., 2020). It is highly unrealistic to teach teacher candidates a wide 
range of approaches and methods and expect them to anticipate useful strategies for real situations in the classroom (Wolff et al., 2020). For this reason, teacher candidates often have a hard time performing in the real classroom, especially when confronted with students' problem behaviors that are challenging for them (Larson et al., 2020). The complexity of leading a classroom and developing expertise in CM requires not only theoretical knowledge but also experience in a variety of classroom situations (Weber et al., 2018). Therefore, it is very important to provide teacher candidates with theoretical information on how to solve CM problems and to present real-life experiences in teacher training programs (Eisenman et al., 2015). Just after providing theoretical knowledge to teacher candidates assigning them directly in the real classroom environment may be a bit challenging for them. Hence, it will be beneficial to offer teacher candidates sequential (step by step) practice opportunities that increase in complexity over time while teaching them complex skills such as effective CM strategies (Cohen et al., 2020). In such a sequential practice, some activities can be organized for the candidates to try what they have learned and engage in classroom-based scenarios. For example, Eisenman et al. (2015) developed practical activities such as film study, microteaching, an animated video, an observation protocol, and a personal management system. Such activities aim to provide teacher candidates with opportunities to put theoretical knowledge into practice.

Another practice used in teacher education is that pre-service teachers perform roles and rehearsals with other pre-service teachers who play the role of K-12 students, thus getting the chance to watch themselves and get feedback (Cohen et al., 2020). Role plays have been used for many years to develop teacher candidates' perspectives and skills in regards to classroom behaviors and CM. In addition to role plays, other means are also used for teacher candidates to respond such as non-interactive animation, sound, text or images (McGarr, 2021). As part of the digital revolution, the use of innovative technologies is becoming widespread in university-based teacher training programs in recent years. Podcasts with educational content, Bug-in-Ear coaching, simulations such as virtual reality, augmented reality and mixed reality are examples of innovative technologies used for teacher training (Larson et al., 2020).

\section{Simulation to Overcome Lack of Practice}

The use of simulations which has potential to save CM training from utilizing only theoretical knowledge is becoming increasingly common. In the last two decades, simulation-based virtual training environments such as Augmented Reality and Virtual Reality have been successfully applied in various fields such as firefighter training, health training, and safety training. Simulated training environments have many advantages over traditional education. First, simulations can provide training conditions for situations that are dangerous, too costly, or impossible to reproduce (e.g. aircraft piloting, interventions to dangerous chemical accidents). Second, simulations create a virtual environment where errors do not affect reality and allow users to repeat the training until the goals are achieved. Third, simulations support active learning that provides hands-on experiences by exposing users to situations that require their intervention (Delamarre et al., 2019). Studies show that simulations feel more realistic than approaches such as role-playing or rehearsals and that people trained in the simulator respond more closely to the behaviors expected of them in real-life situations. Simulations in teacher training can be presented before the real classroom experience, allowing teacher candidates to develop their skills in more standardized and less complex environments. With the help of simulators, these skills are enriched over time and teacher candidates specialize in scenarios that may be encountered during real classroom experiences (Cohen et al., 2020).

Virtual classrooms with virtual students who can imitate human social behavior make it possible to create interactive simulation environments designed to develop social skills. Scenarios in which teacher candidates can improve their communication skills in high-stress situations and be exposed to disturbing virtual students' problem behaviors in a controlled manner can be developed by using such virtual environments (Delamarre et al., 2019). Lugrin et al. (2016) created a virtual classroom to develop an environment for teacher candidates to test and improve their knowledge. The virtual students in this environment created with virtual reality can be controlled autonomously or by teleoperation (remote control by another user), and thus, desired classroom and student behaviors can be created in a controlled manner. With wearable virtual reality headsets, teacher candidates can see themselves in these virtual classrooms and move freely in certain areas. A similar study was conducted by Mahon et al. (2010) who created a virtual classroom by using "Second Life", a web tool established for social sharing. The teacher candidates participating in this study expressed their beliefs that the virtual classroom environment would be beneficial for their professional development.

Teacher candidates may not have adequate information about using effective CM strategies properly, predicting the effects of their CM decisions on students, and determining the aspects that need improvement. For 
this reason, providing feedback to teacher candidates by expert teacher educators is crucial during the activities prepared with simulation environments. A specialist educator should support teacher candidates who use the simulation to develop expertise by providing insights into their strengths and weaknesses, the possible effects of their instructional choice on student outcomes, and strategies for improvement (Cohen et al., 2020). Pas et al. (2019) implemented a 4-month program to help teachers for coping with peer bullying at schools by improving their behavior management skills. During the program, teachers were provided training with a coaching model including expert educator support (EES) and simulator practice, about strategies that are related to detection, prevention, and responding to students bullying behaviors. The participants of this study conducted with an experimental design with a control group were 78 secondary school teachers. According to research results, teachers who received training with EES and simulator practice were more successful in coping with peer bullying than those who did not. New teachers and teacher candidates need more practice opportunities to develop their CM skills to cope with students' problem behaviors before starting to teach in real classrooms. Thanks to simulations that include EES, effective solutions can be generated for creating practice opportunities in teaching various strategies, especially CM (Pas et al., 2019).

\section{Classroom Management Training for In-Service Teachers}

Because individual differences in classrooms are increasingly diverse, one of the high-priority needs of new teachers - and of course experienced teachers - is to get support in using effective CM strategies. The use of workshops, also called in-service training, is a common practice for teacher professional development in many parts of the world. Traditional workshops are useful since they give teachers more time to learn about new techniques and develop a deeper understanding before real classroom practices. However, there is insufficient evidence that such practices, which require a large amount of effort, time, and money each year, can make the desired change in teacher attitudes and behaviors or classroom learning outcomes (Cilliers et al., 2020). In other words, more traditional forms of education, such as workshops, do not provide sufficient support for teachers who wish and need to improve their classroom culture (Reinke et al., 2008). Many studies in the United States support the view that such professional development programs have no impact on student learning, particularly when run by the government on a large scale (Cilliers et al., 2020). Similar findings were found in two studies conducted in Turkey as well. In the first of these studies, Güner (2011) implemented a training program similar to in-service training to improve CM skills of teachers working in inclusive classes in general education schools. The findings showed that while the traditional curriculum increased the theoretical knowledge of teachers about CM, it did not cause a significant change in their level of using these strategies in the teaching process. In the second study (Sucuoğlu et al., 2015), a teacher education program including topics related to inclusion and effective strategies for inclusive classrooms was implemented; however, although the findings show that the program had a moderateto-large effect on teachers' outcomes, it has been found that the effect on teachers' classroom behavior was minimal. Ertürk (2019) emphasizes that the problems related to the effectiveness of in-service training in Turkey are also reported by the Ministry of National Education (MoNE), but no concrete development has been achieved so far.

\section{Training that Combine Theory and Practice: Expert Educator Support (EES)}

Studies conducted in the field show that one-off traditional workshops, the most common form of teacher professional development programs, are largely ineffective and often lead to limited skill transfer and poor learning outcomes. The failure of workshop-style models is related to the lack of two critical components: "engagement with implementation" and "getting support during implementation". Many traditional models focus solely on knowledge transfer (Cilliers et al., 2020). However, in order to provide teachers with an effective professional development opportunity the necessary support throughout the process have to be provided. Considerable time and practice are required to transform skills into mastery if the required guidance and support are not provided. Studies show that providing support in the form of observation, practice, and performance feedback in the early implementation stages can facilitate and accelerate teachers' mastery of new skills (Akalın \& Sucuoğlu, 2015; Reinke et al., 2008; Timuçin, 2008). It is known that people can be more successful when allowed to think and make decisions about behavior change. Therefore, teacher professional development should be approached as a dynamic and active process in which they can directly engage in student work, receive direct feedback about their teaching, or review their practices in their class (Reinke et al., 2008). In other words, theory and practical information should be presented in a blended manner in teacher professional development programs (Emmer \& Stough, 2001). 
To combine theory and practical information and provide useful feedback to teachers coaching and mentoring practices are increasing. These practices, having provided expert educator support (EES), can fill the gap in "engagement with implementation" and "getting support during implementation" because they allow classroom-based practices (Pas et al., 2016). The findings of many studies support EES as an effective method to improve teachers' classroom practices (Akalın \& Sucuoğlu, 2015; Ennis et al., 2020; Timuçin, 2008). The metaanalysis study conducted by Kraft et al. (2018) examined the effects of 44 studies on EES and concluded that EES had an immense effect on measured teacher behaviors and student achievement (Cohen et al., 2020). Güner-Y1ldız and Kurtova (2017) implemented an EES program to find solutions to behavior and learning problems in the first grade of an inclusive primary school where students with adaptation difficulties due to differences in their individual needs were regarded as the source of problems. The findings obtained from this study revealed that the teacher showed behavioral changes that positively affected the classroom layout as a result of receiving individual counseling and support. Among these changes, there are preventing problem behaviors, using rewards to increase students' appropriate behaviors, giving consistent responses to students' behaviors, and making appropriate teaching arrangements by the individual differences of students with special needs in the classroom. In two separate studies, after a training program was applied, expert support with performance feedback was provided to teachers. In the first of these studies, Akalın and Sucuoğlu (2015) examined the effect of daily performance feedback after being given training on classroom management strategies on teacher and student outcomes. The study results showed that the academic participation of the students increased along with the preventive classroom management skills of the teachers. In the second study, İşcen-Karasu (2017) trained teachers working in inclusive preschool classrooms on preventive classroom management strategies, and then provided performance feedback on target strategies. The findings of the study showed that the feedback provided to teachers by the expert individually and until the teachers became independent in their target behaviors, led to positive outcomes for both teachers and their students.

Another study experimentally compared the two in-service professional development approaches for teachers of 180 primary schools in the Republic of South Africa. The first approach was the traditional in-service training model (short, intensive training organized in a central location) used by many governments, while the second approach was coaching, where expert educators visited teachers monthly to observe their teaching practices and provided feedback. Results demonstrated that coaching had a statistically significant effect on student reading competence, a ratio more than twice that of traditional in-service training (Cilliers et al., 2020). With the accumulation of scientific evidence, the field of in-service professional development unites around the idea that EES is one of the most effective ways to support teacher professional development (Cohen et al., 2020). Parallel to this, EES is becoming an increasingly popular method for increasing teacher effectiveness and supporting teachers' professional development (Ennis et al., 2020).

The EES models presented in the literature differ in terms of focus and effectiveness. However, existing programs generally share many critical features such as job-embedded practice, intensive and long-term collaboration (Desimone \& Pak, 2017). Unlike the traditional workshop model, EES models include components of active learning approaches (for example, modeling, implementation, and feedback) to facilitate teacher skill development. Most EES programs emphasize that expert educators should respond to observed teacher needs, prompt teachers to evaluate their practice, and provide more guiding feedback to support their development if the teacher needs (Cohen et al., 2020). EES cycles typically consist of classroom observations followed by targeted feedback on teachers' practices and specific suggestions for improvement. These cycles may be implemented over a full academic year or longer and expert educators can provide personalized feedback by working one-on-one with teachers or in small groups (Kraft et al., 2018).

It should not be forgotten that the individuals who will serve as expert educators must have certain skills and competencies. Expert educators are expected to be competent in data collection, goal setting, planning and time management, designing and presenting effective professional development programs, communication and problem solving, as well as building trust, confidentiality, and professional ethics (Denton \& Hasbrouck, 2009).

\section{Discussion}

\section{Proposed Solution within the Framework of 2023 Education Vision}

Lack of practice in teacher training programs, inadequate support for newly recruited teachers, and the inability to effectively sustain the professional development of teachers on active duty are the main problems in $\mathrm{CM}$. At the same time, the fact that schools are more and more inclusive every day makes it imperative to use new and effective strategies in ensuring teacher preparation and development in CM. Each teacher candidate should 
graduate from education faculties after attaining the level of competence that allows performing effective CM applications and using methods in classes consisting of children with different individual characteristics to ensure the success of their students. Teachers who are now on active duty need to be re-trained within the framework of inclusive education and learn to use effective CM strategies. Taking steps to ensure the development of active teachers together with teacher candidates on $\mathrm{CM}$ within the framework of a national plan is important for both inclusive education and the success of teachers and students.

MoNE undertakes initiatives to identify the shortcomings of the education system and to produce radical solutions to existing problems. One of these initiatives is the "2023 Education Vision" document published in 2018 (MoNE, 2020). This document is regarded as an important development since it contains a roadmap outlining the changes and transformations planned for the education system. One of the important issues addressed in the vision document is the development and management of human resources (Elçiçek \& Han, 2018). Regarding human resources, the 2023 Education Vision states the following: "Teacher training programs will be specifically restructured by focusing on the practice of teaching at those education faculties fulfilling the defined criteria across Turkey" (MoNE, 2020). As this statement indicates, transformations are planned in some teacher training programs and more emphasis will be placed on practice (Ertürk, 2019). Thanks to this positive development, teacher candidates will find more opportunities to reflect their theoretical knowledge into practice. Here, there are some points to be considered in light of the findings in the literature in creating practice opportunities for teacher candidates.

\section{Hands-on Classroom Management Training for Teacher Candidates}

Intermediary steps should exist between teacher candidates' theoretical training and their face-to-face school practices with students in real classrooms (Cohen et al., 2020). Thus, rather than being directly exposed to real classroom events, teacher candidates will be able to make a gradual transition. The literature presents various studies focusing on opportunities for teacher candidates to practice CM. For example, it was discussed in a study (Siebert, 2005) a formation called School Professional Development Initiative which provides opportunities to use effective CM strategies in classrooms for teacher candidates who did not have the chance to practice adequately during their education at university. Eisenman et al. (2015), on the other hand, aimed to combine theory and practice in training teacher candidates by developing practical activities such as film work, micro-teaching, an animated video, an observation protocol, and a personal management system. Besides, technology can also be used to combine theory and practice. Simulation is one of the technologies with the potential to produce effective solutions in this regard. There are national-scale projects that have already been developed or under development in our country to benefit from the potential of simulation technologies, especially in the training of our aviation and security units (Hava Elektronik Sanayi [HAVELSAN], 2020; Middle East Technical University [METU], 2020). Thanks to simulations, our security units and pilots have the opportunity to practice their theoretical knowledge before they are exposed to real situations (Özmen \& Denktaş, 2011). A similar initiative can be undertaken at the national level in the field of education to develop simulations for teacher training. To develop a qualified simulator that includes a classroom full of virtual students who can be mobilized and exhibit social behaviors through autonomous and teleoperations, first of all, should be determine requirements and design an appropriate model in cooperation with the Ministry of National Education and Council of Higher Education. It will be beneficial to develop a simulator or various simulators that can be used in teacher training programs with a national scale project by working with universities, institutions, and organizations with competence in simulation technologies. Providing EES to teacher candidates during practice activities created with simulation technologies or by other means, and thus, ensuring a closely monitored application process, constructive feedback and personal reflections on their performance with the help of expert educators will further increase the quality of teaching (Reinke et al., 2008). In this way, teacher candidates will be able to move on to the face-to-face practice phase with their real students in a more qualified manner.

Teaching practice by teacher candidates in schools affiliated to the MoNE is also important in preparing them to teach in real classrooms. This practice aims "teacher candidates will be better prepared for the teaching profession and have the competence to use the general culture, special field education, and the knowledge, skills, attitudes, and behaviors they have acquired during their education in a real educational environment" (MoNE, 2018). In a study on teaching practice, Ekinci et al. (2019) examined the opinions of 207 pre-service teachers and 179 mentors who were assigned to guide prospective teachers in the 2015-2016 academic year, on teaching practices. The followings were among the prominent findings of the study: "sharing professional development and educational experiences is important" and "the implemented program does not help teacher candidates to acquire the targeted competencies and therefore does not achieve its purpose". The solutions presented by the researchers 
to solve the problem, namely, "improvement of the conditions for mentoring and making it more attractive" and "seeking competence in mentor teachers" is rather significant.

Identifying and training expert educators who will support teacher candidates during the implementation process is an issue that needs to be taken into consideration when organizing face-to-face teaching practices for teacher candidates. In accordance with the Teaching Practice Directive published in 2018, teachers who will guide teacher candidates are required to have a "Teaching Practice Training Certificate issued by the Ministry of National Education" (MoNE, 2018). As can be understood from this statement, the criteria for having a certificate has been introduced for teachers to be assigned in teaching practices as of 2018. But, teachers can obtain this certificate through a short-term traditional workshop. Whereas, since the competencies of the mentor teachers who work as expert educators are critical for achieving the desired goals of these applications, which are a type of EES, how this certificate is given should be taken into consideration. Having experience in the profession, having an inservice training certificate from a specific workshop, or feeling self-sufficient may not demonstrate competence (Ekinci et al., 2019; Poulou et al., 2019). For this reason, choosing mentor teachers who will provide EES from among teachers who are successful in professional terms, especially in CM, will increase the quality of the implementation.

The Teaching Practice Directive (MoNE, 2018) also states that "the competencies of the personnel participating in teaching practices and the application process are evaluated and continuously improved". In line with this statement, it is necessary to provide professional development opportunities to develop the competencies of the expert educators/mentor teachers selected to guide prospective teachers in terms of both CM and EES. Thus, as the professional success of mentor teachers will increase over time, the quality of the application opportunities provided to pre-service teachers will also increase.

\section{Classroom Management Training for Teachers on Active Duty}

Professional development is important for teachers on active duty as much as it is for teacher candidates. The 2023 Education Vision points out that certain developments are targeted in this regard (MoNE, 2020). The following statements are included in the vision document:

1. Some of the in-service training activities for teachers and school administrators will be converted from the practice of a participation certification to that of an accredited certification program to be run by universities.

2. Professional development activities will be supported with post-graduate education.

The emphasis on cooperation with universities in regards to teachers' professional development is a positive development. However, the vision document does not contain clear information about the steps that will be taken about school-based professional development (Elçiçek \& Han, 2018). Developing teachers' CM competencies with school-based activities is important for effective teacher training (Korb et al., 2016). In addition to the university-based certificate programs to be carried out in cooperation with the Council of Higher Education, teachers who need support in professional development should be determined by objective methods and individual or small group EES should be provided for them. To increase the success of EES applications, experienced teachers who will provide EES to their colleagues should be determined according to objective criteria in teaching and CM issues. In addition, the professional development of these successful teachers should be supported to become better expert educators.

To increase the success of the teaching profession in general, all teachers should be encouraged in professional development and the professional development of experienced and successful teachers in becoming expert educators made attractive and encouraged. For example, gains in inter-school relocation, manager appointments, and salary can be considered as incentives. In addition, the teacher career steps system (MoNE, 2020), planned to implement in the near future by the Ministry of National Education, can be a tool that can be used for this purpose. Because the career steps system is seen as a system that supports and encourages teachers' professional development (Bakioğlu \& Banoğlu, 2013). The vision document states the following regarding the career steps: "Horizontal and vertical career specialization areas will be structured for teachers and school administrators" and "post-graduate professional specialization programs will be launched to enable both horizontal and vertical career steps" (MoNE, 2020). Using school-based professional development programs in addition to graduate education programs in the career steps system will have the potential to further support teachers' development in CM as it includes hands-on training. Active teachers' CM skills should be measured with objective 
methods and become a criterion for progress in career steps and thus the career steps system should be a source of motivation for teachers' professional development.

In summary, four important points should not be overlooked while training active teachers on CM. The first is the need to prepare teachers candidates to work in inclusive classrooms and to be able to differentiate their methods and strategies in accordance with students' learning and behavior characteristics. For this, it is suggested that CM training should be planned in a way that will include strategies that can respond to learning and behavioral problems in inclusive classrooms and provide practice opportunities to prospective teachers at various levels (feedback, role-playing, simulation use, coaching, or mentoring, etc.). Second, it is necessary to use methods that include school-based practices for teacher professional development rather than providing theoretical knowledge with intensive and short-term traditional workshops. In particular, it is necessary to determine the support needs of teachers working in inclusive classrooms and to provide EES in line with their needs. Thirdly, teachers to be appointed as expert educators should be determined according to objective criteria in terms of professional success and competencies in the CM. Also, their professional development should be supported throughout their expert educator career. Fourth, all teachers should be encouraged in their professional development. For this purpose, the teaching career ladder system should be used more effectively. However, it is possible to claim that the starting point is increasing the stakeholders' awareness about the importance of CM. It is known that CM is an area that is not adequately addressed in the education community despite its great importance for teachers' and students' success (Evertson \& Weinstein, 2013). For this reason, to increase motivation for CM studies, informative activities regarding the findings of studies that demonstrate the effect of CM on student behavior and success should be carried out in education faculties and in institutions employing teachers.

\section{Authors' Contributions}

The idea, design, and critical review processes of this study were carried out by the first author Nevin Güner-Yıldız. Hasan Köse and Esra Akın carried out the literature review phase of the study. All three authors took part in the writing process. Esra Akın and Hasan Köse actively took part in the editing and final correction processes according to the related journal. 


\section{References}

Akalın, S., \& Sucuoğlu, B. (2015). Effects of classroom management intervention based on teacher training and performance feedback on outcomes of teacher-student dyads in inclusive classrooms. Educational Sciences: Theory and Practice, 15(3), 739-758. https://doi.org/10.12738/estp.2015.3.2543

Ali, Z. B. M., Wahi, W., \& Yamat, H. (2018). A review of teacher coaching and mentoring approach. International Journal of Academic Research in Business and Social Sciences, 8(8), 504-524. https://doi.org/10.6007/IJARBSS/v8-i8/4609

Babaoğlan, E., \& Yılmaz, Ş. (2010). Sınıf öğretmenlerinin kaynaştırma eğitimindeki yeterlikleri [Classroom teachers' competencies in inclusive education]. Kastamonu Eğitim Dergisi, 18(2), 345-354. https://dergipark.org.tr/en/pub/kefdergi/issue/49063/626026

Bakioğlu, A., \& Banoğlu, K. (2013). Öğretmenlikte kariyer basamakları uygulamasına ilişkin öğretmen görüşlerinin metaforlar ve sosyal ağ analizi yöntemiyle incelenmesi [Investigation of teacher views on teachers career stages system through metaphors and social network analysis]. Marmara Üniversitesi Atatürk Eğitim Fakültesi Eğitim Bilimleri Dergisi, 37, 28-55. https://biblio.ugent.be/publication/6884343

Brophy, J. (2013). History of research on classroom management. In C. M. Evertson \& C. S. Weinstein (Eds.), Handbook of classroom management: Research, practice, and contemporary issues (pp. 17-43). Routledge.

Carneiro, R. U. C., Dall'Acqua, M. J. C., \& Caramori, P. M. (2015). School inclusion and classroom management: Challenges and possibilities. Creative Education, 6(19), 2037-2044. https://doi.org/10.4236/ce.2015.619209

Cilliers, J., Fleisch, B., Prinsloo, C., \& Taylor, S. (2020). How to improve teaching practice? An experimental comparison of centralized training and in-classroom coaching. Journal of Human Resources, 55(3), 926962. https://doi.org/10.3368/jhr.55.3.0618-9538R1

Civitillo, S., De Moor, J. M., \& Vervloed, M. P. (2016). Pre-service teachers' beliefs about inclusive education in the Netherlands: An exploratory study. Support for Learning, 31(2), 104-121. https://doi.org/10.1111/1467-9604.12119

Cohen, J., Wong, V., Krishnamachari, A., \& Berlin, R. (2020). Teacher coaching in a simulated environment. Educational Evaluation and Policy Analysis, 42(2), 208-231. https://doi.org/10.3102/0162373720906217

Daniels, V. I. (1998). How to manage disruptive behavior in inclusive classrooms. Teaching Exceptional Children, 30(4), 26-31. https://doi.org/10.1177/004005999803000405

Delamarre, A., Buche, C., \& Lisetti, C. (2019, July 2-5). AIMER: Appraisal interpersonal model of emotion regulation, affective virtual students to support teachers training [Conference session]. Proceedings of the $19^{\text {th }}$ ACM International Conference on Intelligent Virtual Agents, Paris, France. https://dl.acm.org/doi/proceedings/10.1145/3308532

Denton, C. A., \& Hasbrouck, J. (2009). A description of instructional coaching and its relationship to consultation. Journal of Educational and Psychological Consultation, 19(2), 150-175. https://doi.org/10.1080/10474410802463296

Desimone, L. M., \& Pak, K. (2017). Instructional coaching as high-quality professional development. Theory into Practice, 56(1), 3-12. https://doi.org/10.1080/00405841.2016.1241947

Dinsmore, T. S. (2003). Classroom management. https://files.eric.ed.gov/fulltext/ED478771.pdf

Eisenman, G., Edwards, S., \& Cushman, C. A. (2015). Bringing reality to classroom management in teacher education. Professional Educator, 39(1). https://eric.ed.gov/?id=EJ1062280

Ekinci, A., Bozan, S., \& Sakız, H. (2019). Aday öğretmen yetiştirme programının etkililiğine ilişkin aday ve danışman öğretmen görüşlerinin değerlendirilmesi [Evaluation of the opinions of candidate and advisor teachers regarding the effectiveness of the prospective teacher training program]. Ankara Üniversitesi Ĕgitim Bilimleri Fakültesi Dergisi, 52(3), 801-836. https://doi.org/10.30964/auebfd.466469 
Elçiçek, Z., \& Han, B. (2018). Evaluation of 2023 education vision. In K. Akkılıç, M. E. Asker, M. Y1lmaz, B. Gümüş, H. Kılıç, \& Z. Gülsüm (Eds.), Inesec International Social Sciences and Education Conference (pp. 250-258). http://www.inesegconferences.org/issec/wp-content/uploads/2018/12/ISSEC\%20v12.pdf

Emmer, E. T., \& Stough, L. M. (2001). Classroom management: A critical part of educational psychology, with implications for teacher education. Educational Psychologist, 36(2), 103-112. https://doi.org/10.1207/S15326985EP3602_5

Ennis, R. P., Royer, D. J., Lane, K. L., \& Dunlap, K. D. (2020). The impact of coaching on teacher-delivered behavior-specific praise in Pre-K-12 settings: A systematic review. Behavioral Disorders, 45(3), 148166. https://doi.org/10.1177/0198742919839221

Ertürk, A. (2019). 2023 Eğitim vizyonu: Sorunlara çare mi? [Education vision for 2023: Solution to problems?]. Pamukkale Üniversitesi Ĕ̈itim Fakültesi Dergisi, 48, 321-325. https://doi.org/10.9779/pauefd.537273

Evertson, C. M., \& Weinstein, C. S. (2013). Classroom management as a field of inquiry. In C. M. Evertson \& C. S. Weinstein (Eds.), Handbook of classroom management: Research, practice, and contemporary issues (pp. 3-15). Routledge.

Flower, A., McKenna, J. W., \& Haring, C. D. (2017). Behavior and classroom management: Are teacher preparation programs really preparing our teachers? Preventing School Failure: Alternative Education for Children and Youth, 61(2), 163-169. https://doi.org/10.1080/1045988X.2016.1231109

Gage, N. A., Scott, T., Hirn, R., \& MacSuga-Gage, A. S. (2018). The relationship between teachers' implementation of classroom management practices and student behavior in elementary school. Behavioral Disorders, 43(2), 302-315. https://doi.org/10.1177/0198742917714809

Gaias, L. M., Lindstrom-Johnson, S., Bottiani, J. H., Debnam, K. J., \& Bradshaw, C. P. (2019). Examining teachers' classroom management profiles: Incorporating a focus on culturally responsive practice. Journal of School Psychology, 76, 124-139. https://doi.org/10.1016/j.jsp.2019.07.017

Gök, R. (2013). Kaynaştırma ĕgitimi öğrencisi bulunan ilkokul sınıf öğretmenlerinin sınıf yönetiminde karşılaştıkları zorluklar ve bu zorluklara başa çıkma yöntemleri [Challenges faced by primary school classroom teachers with inclusive education students and the methods of collecting these challenges] (Tez Numarası: 321934) [Yüksek lisans tezi, Akdeniz Üniversitesi]. Yükseköğretim Kurulu Ulusal Tez Merkezi.

Güner-Yıldız, N., \& Kurtova, C. (2017). Sınıf sorunlarına eylem araştırmasıyla çözüm arayışı [Seeking solutions for the classroom problems through action research]. Elementary Education Online, 16(1), 78-88. https://core.ac.uk/download/pdf/230027714.pdf

Güner, N. (2011). Önleyici sınıf yönetimi eğitim programı'nın kaynaştırma sınıflarında çalışan öğretmenlerin sınıf yönetimine etkisi [The effect of preventive classroom management training program on classroom management of teachers working in inclusive classrooms]. Gazi Üniversitesi Eğitim Fakültesi Dergisi, 31(1), 273-301. https://dergipark.org.tr/tr/pub/gefad/issue/6739/90602

Hava Elektronik Sanayi. (2020). Eğitim ve simülasyon teknolojileri [Training and simulation technologies]. https://www.havelsan.com.tr/sektorler/egitim-ve-simulasyon

Hemmings, B., \& Woodcock, S. (2011). Preservice teachers' views of inclusive education: A content analysis. Australasian Journal of Special Education, 35(2), 103-116. https://doi.org/10.1375/ajse.35.2.103

İşcen-Karasu, F. (2017). Performans geribildiriminin okul öncesi öğretmenlerinin önleyici sinıf yönetimi stratejileri ile özel gereksinimli çocuk çıktıları üzerindeki etkisi [Effects of performance feedback on preschool teachers' use of preventive classroom management strategies and outcomes of children with special needs] (Tez Numaras1: 468277) [Doktora tezi, Ankara Üniversitesi]. Yükseköğretim Kurulu Ulusal Tez Merkezi.

Jung, W. S. (2007). Preservice teacher training for successful inclusion. Education, 128(1), 106-113. https://web.p.ebscohost.com/ehost/pdfviewer/pdfviewer?vid=2\&sid=e802485f-ba95-43fa-aa090acb0e744828\%40redis 
Kher, N., Lacina-Gifford, L. J., \& Yandell, S. (2000, April 24-28). Preservice teachers' knowledge of effective classroom management strategies: Defiant behavior [Paper presentation]. Annual Meeting of the American Educational Research Association, New Orleans, LA, United States.

Kırılmaz, M. C., \& Öntaş, T. (2020). Sınıf öğretmenlerinin sığınmacılara yönelik kapsayıcı eğitimi gerçekleştirme durumunun incelenmesi [Examining the situation of classroom teachers in realizing inclusive education for refugees]. Journal of Hasan Ali Yücel Faculty of Education, 17(1), 51-82. https://doi.org/10.5152/hayef.2020.19001

Korb, K. A., Selzing-Musa, G., \& Skinner-Bonat, S. B. (2016). The effect of training on teachers' knowledge of effective classroom management strategies in Jos metropolis. Global Journal of Educational Research, 15(1), 79-87. https://doi.org/10.4314/gjedr.v15i1.9

Kraft, M. A., Blazar, D., \& Hogan, D. (2018). The effect of teacher coaching on instruction and achievement: A meta-analysis of the causal evidence. Review of Educational Research, 88(4), 547-588. https://doi.org/10/ggjrhd

Larson, K. E., Hirsch, S. E., McGraw, J. P., \& Bradshaw, C. P. (2020). Preparing preservice teachers to manage behavior problems in the classroom: The feasibility and acceptability of using a mixed-reality simulator. Journal of Special Education Technology, 35(2), 63-75. https://doi.org/10.1177/0162643419836415

Lugrin, J. L., Latoschik, M. E., Habel, M., Roth, D., Seufert, C., \& Grafe, S. (2016). Breaking bad behaviors: A new tool for learning classroom management using virtual reality. Frontiers in ICT, 3(26), 1-21. https://doi.org/10.3389/fict.2016.00026

Mahon, J., Bryant, B., Brown, B., \& Kim, M. (2010). Using second life to enhance classroom management practice in teacher education. Educational Media International, 47(2), 121-134. https://doi.org/10.1080/09523987.2010.492677

McGarr, O. (2021). The use of virtual simulations in teacher education to develop pre-service teachers' behaviour and classroom management skills: Implications for reflective practice. Journal of Education for Teaching, 47(2), 274-286. https://doi.org/10.1080/02607476.2020.1733398

Middle East Technical University. (2020). Taf Modeling and Simulation R\&D Center. http://modsim.metu.edu.tr/en/

Milli Eğitim Bakanlığı [Ministry of National Education]. (2018). Öğretmenlik Uygulaması Yönergesi [Teaching Practice Directive]. https://oygm.meb.gov.tr/meb_iys_dosyalar/2020_07/13135500_Yonerge.pdf

Milli Eğitim Bakanlığı [Ministry of National Education]. (2020). 2023 Eğitim Vizyonu [2023 Education Vision]. http://2023vizyonu.meb.gov.tr/

Mitchem, K. J., \& Benyo, J. (2000, March 16-18). A classwide peer assisted self-management program all teachers can use: Adaptations and implications for rural educators [Paper presentation]. Proceedings of the 2000 Annual national Conference of the American Council on Rural Special Education, Alexandria, VA, United States.

Özmen, F., \& Denktaş, Y. (2011, May 16-18). Türkiye'de polis meslek yüksekokullarının bilişim teknolojisini kullanmadaki etkililiğ $i$ The effectiveness of police vocational schools in using information technology in Turkey] [Paper presentation]. The $6^{\text {th }}$ International Advanced Technologies Symposium, Elazığ, Turkey.

Pas, E. T., Larson, K. E., Reinke, W. M., Herman, K. C., \& Bradshaw, C. P. (2016). Implementation and acceptability of an adapted classroom check-up coaching model to promote culturally responsive classroom management. Education and Treatment of Children, 39(4), 467-491. https://doi.org/10.1353/etc.2016.0021

Pas, E. T., Waasdorp, T. E., \& Bradshaw, C. P. (2019). Coaching teachers to detect, prevent, and respond to bullying using mixed reality simulation: An efficacy study in middle schools. International Journal of Bullying Prevention, 1(1), 58-69. https://doi.org/10.1007/s42380-018-0003-0

Poulou, M. S., Reddy, L. A., \& Dudek, C. M. (2019). Relation of teacher self-efficacy and classroom practices: A preliminary investigation. School Psychology International, 40(1), 25-48. https://doi.org/10.1177\%2F0143034318798045 
Reinke, W. M., Sprick, R., \& Knight, J. (2008). Coaching classroom management. In J. Knight (Ed.), Coaching: Approaches and perspectives (pp. 91-112). Corwin Press.

Sadioğlu, Ö., Bilgin, A., Batu, S., \& Oksal, A. (2013). Sınıf öğretmenlerinin kaynaştırmaya ilişkin sorunları, beklentileri ve önerileri [Problems, expectations and suggestions of classroom teachers regarding mainstreaming]. Educational Sciences: Theory \& Practice, 13(3), 1743-1765. https://eric.ed.gov/?id=EJ1017690

Siebert, C. J. (2005). Promoting preservice teachers' success in classroom management by leveraging a local union's resources: A professional development school initiative. Education, 125(3), 385-392. https://web.a.ebscohost.com/ehost/pdfviewer/pdfviewer?vid=2\&sid=46335be3-3b9b-4bb8-908c1f472d09b385\%40sdc-V-sessmgr01

Simonsen, B., Fairbanks, S., Briesch, A., Myers, D., \& Sugai, G. (2008). Evidence-based practices in classroom management: Considerations for research to practice. Education and Treatment of Children, 31(3), 351-380. https://www.jstor.org/stable/42899983

Sucuoğlu, B., Bakkaloğlu, H., Akalın, S., Demir, Ş., \& İşcen-Karasu, F. (2015). The effects of the preschool inclusion program on teacher outcomes in Turkey. Journal of Early Childhood Teacher Education, 36(4), 324-341. https://doi.org/10.1080/10901027.2015.1105328

Sucuoğlu, B., Bakkaloğlu, H., İşcen-Karasu, F., Demir, Ş., \& Akalın, S. (2014). Okul öncesi öğretmenlerinin kaynaştırmaya ilişkin bilgi düzeyleri [Pre-school teachers' knowledge levels on inclusion]. Kuram ve Uygulamada Ĕgitim Bilimleri, 14(4), 1467-1485. http://doi.org/10.12738/estp.2014.4.2078

Sucuoğlu, N. B., Bayraklı, H., İşcen-Karasu, F., \& Demir, Ş. (2017). The preschool classroom management and inclusion in Turkey. International Journal of Early Childhood Special Education, 9(2), 66-80. https://www.intjecse.net/abstract.php?id=129

Thaver, T., \& Lim, L. (2014). Attitudes of pre-service mainstream teachers in Singapore towards people with disabilities and inclusive education. International Journal of Inclusive Education, 18(10), 1038-1052. https://doi.org/10.1080/13603116.2012.693399

Timuçin, E. U. (2008). Doğrudan davranışsal danışmanlı̆̆ın birlikte eğitim ortamına yerleştirilmiş yetersizliği olan ögrencilerin problem davranışların azaltmadaki etkililiği [The effectiveness of the direct behavioral consultation on the problem behaviors of the handicapped students who were placed into regular school settings] (Tez Numarası: 227848) [Doktora tezi, Gazi Üniversitesi]. Yükseköğretim Kurulu Ulusal Tez Merkezi.

Tripp, L. O., \& Seals, C. D. (2017). The use of animated case studies as a tool to influence pre-service teachers preparedness in classroom management. International Journal of Education and Social Science, 4(3), 33-41. http://www.ijessnet.com/uploades/volumes/1598723857.pdf

United Nations Educational Scientific and Cultural Organization. (1994). World conference on special needs education: Access and quality; final report. World Conference on Special Needs Education: Access and Quality, Salamanca, Spain. https://unesdoc.unesco.org/ark:/48223/pf0000110753

Ünal, R., \& Aladağ, S. (2020). Investigation of problems and solution proposals in the context of inclusive education practices. Journal of Interdisciplinary Education: Theory and Practice, 2(1), 23-42. https://dergipark.org.tr/tr/download/article-file/1121494

Veenman, S. (1984). Perceived problems of beginning teachers. Review of Educational Research, 54(2), 143-178. https://journals.sagepub.com/doi/abs/10.3102/00346543054002143

Weber, K. E., Gold, B., Prilop, C. N., \& Kleinknecht, M. (2018). Promoting pre-service teachers' professional vision of classroom management during practical school training: Effects of a structured online-and video-based selfreflection and feedback intervention. Teaching and Teacher Education, 76(1), 39-49. https://doi.org/10.1016/j.tate.2018.08.008

Wolff, C. E., Jarodzka, H., \& Boshuizen, H. P. (2020). Classroom management scripts: A theoretical model contrasting expert and novice teachers' knowledge and awareness of classroom events. Educational Psychology Review, 33(1), 131-148. https://doi.org/10.1007/s10648-020-09542-0

Zuckerman, J. T. (2007). Classroom management in secondary schools: A study of student teachers' successful strategies. American Secondary Education, 35(2), 4-16. https://www.jstor.org/stable/41406285 


\section{Ankara Üniversitesi Eğitim Bilimleri Fakültesi Özel Eğitim Dergisi}

2022, 23(3), 699-720

\section{DERLEME}

Gönderim Tarihi: 07.01.20

Kabul Tarihi: 07.09.21

Erken Görünüm: 02.11.21

\section{Sınıf Yönetimi: Kapsayıcı Eğitim Çerçevesinde Önemi, Güncel Sorunlar ve Çözüm Önerileri}

\author{
Nevin Güner-Yıldız $\mathbb{D} 1$
}

\author{
Hasan Köse ${ }^{(\mathbb{D}) 2}$
}

\author{
Esra Akın 3
}

$\ddot{O} z$

Giriş: Öğretmenlerin etkili sınıf yönetimi (SY) stratejilerini biliyor ve etkin bir şekilde kullanabiliyor olmasının öğretmenlerin mesleki başarısı ve öğrencilerin öğrenme çıktıları üzerinde olumlu bir etkisi olduğu bilinmektedir. Öğretmenlerin kullanabilecekleri etkili stratejiler günümüze kadar yapılan çeşitli bilimsel çalışmalarla ortaya konulmuştur. Ancak bu stratejiler uygulamada çeşitli nedenlerle yeterince kullanılmamaktadır ve bu nedenle birçok sınıfta öğrencilerin problem davranışlarını kontrol etmek, öğrencileri etkinliklere odaklamak ve etkili eğitimi sürdürmek henüz öğretmenlerin yeterince başarabildiği bir görev değildir. Bununla birlikte gün geçtikçe daha kapsayıcı hale gelen eğitim ortamları ve artan öğrenci çeşitliliği SY konusundaki problemlerin karmaşıklığını da arttırmaktadır. Bu çalışmanın amacı, alanyazındaki bilgiler ışığında günümüzde öğretmenlerin SY konusunda yaşadığı güçlükler ile bu güçlüklerin nedenlerinin belirlenmesi ve çözüm için kullanılabilecek araçların ortaya konmasidır.

Tartışma: Bu çalışma kapsamında Türkiye Cumhuriyeti Millî Eğitim Bakanlığının (MEB) eğitim sistemindeki sorunların ç̧̈zümüne yönelik hazırladığı kısa vadeli yol haritası olan "2023 Eğitim Vizyonu” belgesi, SY ile ilgili sorunların çözümü hakkındaki içerikleri bakımından incelenmiş ve karar alıcılara SY konusunda atılabilecek adımlar ile ilgili somut önerilerde bulunulmuştur.

Anahtar kelimeler: Sınıf yönetimi, öğretmen eğitimi, kapsayıcı eğitim, 2023 eğitim vizyonu, simülasyon, koçluk.

Atıf için: Güner-Yıldız, N., Köse, H., \& Akın, E. (2022). Sınıf yönetimi: Kapsayıcı eğitim çerçevesinde önemi, güncel sorunlar ve çözüm önerileri. Ankara Üniversitesi Eğitim Bilimleri Fakültesi Özel Eğitim Dergisi, 23(3), 699-720. https://doi.org/10.21565/ozelegitimdergisi.856085

\footnotetext{
${ }^{1}$ Sorumlu Yazar: Doç. Dr., Eskişehir Osmangazi Üniversitesi, E-posta: antreh@ gmail.com, https://orcid.org/0000-0002-9135$\underline{6429}$

2Öğretmen, Milli Eğitim Bakanlığı, E-posta: hsnkose@ hotmail.com, https://orcid.org/0000-0002-0923-3711

${ }^{3}$ Arş. Gör., Eskişehir Osmangazi Üniversitesi, E-posta: esraak762@gmail.com, https://orcid.org/0000-0002-7414-1207
} 


\section{Giriş}

Sınıf yönetimi (SY) denilince akla ilk olarak kontrol ve itaati en üst düzeye çıkaran mekanik, otoriter bir yönetim şekli gelebilmekte ve bu bakış açısına sahip kişiler sınıf yönetimini yalnızca 'öğrencileri kontrol etmek' olarak düşünebilmektedirler. Oysa SY öğrencilerin davranışlarını kontrol etmek için kurallar, ödüller ve cezalar oluşturmaktan çok daha karmaşık ve çok yönlü bir çabadır ve başarılı bir SY için uygun fiziksel ortamlar oluşturmaktan ve sınıfı bir grup olarak yönetmekten daha fazlası gerekmektedir (Evertson \& Weinstein, 2013). Evertson ve Weinstein (2013) SY'yi, genel olarak, öğretmenlerin hem akademik hem de sosyal-duygusal gelişimi destekleyen ve kolaylaştıran bir ortam oluşturmak için attığı adımlar olarak tanımlamaktadır. Etkili bir sınıf yönetimi için kullanılabilecek kanıta dayalı stratejiler beş başlık altında gruplandırılabilir. Bunlar; (a) eğitim ortamında fiziksel düzenlemeler yaparak dikkat dağınıklığına neden olabilecek uyaranların azaltılması, (b) öğrencilerin aktif katılımını destekleyici öğretim stratejilerine yer vermek, (c) sınıf kurallarını öğretmek, tutarlı biçimde izlemek ve gerektiğinde öğrencilere geri bildirim sağlamak, (d) öğrencilerin olumlu/uygun davrannışlarını tutarlı biçimde onaylamak ve (e) problem davranışlara karşı tutarlı tepkiler vermek (Simonsen vd., 2008). Etkili SY stratejileri sayesinde öğretmenler, öğrencilerin başarısını, etkinliklere katılım düzeyini ve olumlu akran ilişkilerini geliştirebilir; ders dışı ve yıkıcı olan, öğretmeni ve sınıftaki diğer öğrencileri rahatsız eden problem davranışlarını ise azaltabilirler (Gaias vd., 2019). Yeterli düzeyde SY uzmanlığına sahip öğretmenler, öğrenmeyi en üst düzeye çıkarıp kesintileri en aza indirebilirler ve bu sayede etkili bir öğrenme ortamı sağlayabilirler. Ayrıca, etkili SY öğretmenlerin ruh sağlığını da olumlu yönde etkilemekte, mesleki stresi ve tükenmişliği önlemeye yardımcı olmaktadır (Weber vd., 2018). Bu bakımdan etkili SY stratejileri bir öğretmenin sahip olabileceği en değerli araçlar olarak kabul edilmeli ve öğretmenlerin SY konusundaki mesleki gelişimi desteklenmelidir (Korb vd., 2016).

\section{Sınıf Yönetimi ve Kapsayıcı Eğitim}

Kısaca okulların tüm çocuklara, özellikle özel eğitim gereksinimi olanlara hizmet vermesini sağlamak olarak tanımlanan kapsayıcı eğitim (United Nations Educational, Scientific and Cultural Organization [UNESCO], 1994) uygulamaları dünya genelinde giderek yaygınlaşmaktadır (Emmer \& Stough, 2001). Aynı zamanda kapsayıcı eğitim uygulamaları yapılan sınıflarda öğrenci çeşitliliği artmakta ve bu durum öğretmenlerin farklı öğrenme gereksinimlerine uygun çözümler üretmesini zorunlu k1lmaktadır (Carneiro vd., 2015). Ancak alan yazında kaynaştırma sınıflarında çalışan öğretmenlerin genellikle özel gereksinimli öğrencilere eğitim verme konusunda kendilerini hazırlıksız hissettikleri ve kaynaştırmaya yönelik olumsuz tutumlara sahip oldukları vurgulanmaktadır (Civitillo vd., 2016; Hemmings \& Woodcock, 2011; Sadioğlu vd., 2013). Ayrıca yapılan araştırmalar öğretmenlerin kaynaştırma uygulamalarıyla bilgilerinin yetersiz olduğunu (Sucuoğlu vd., 2014; Thaver \& Lim, 2014) ve öğretmenlerin özel gereksinimli çocukların problem davranışları nedeniyle bu çocukları sınıflarına kabul etmek istemediklerini ortaya koymaktadır (Daniels, 1998; Mitchem \& Benyo, 2000). Öğretmenlerin kapsayıcı eğitime yönelik bu tutumlarının öz-yeterlik algılarıyla ilişsili olduğu bilinmektedir. Özyeterlik algısındaki düşüklük ise öğretmenlerin kendi öğretim becerilerine, özellikle de SY becerilerine olan güvensizliğini yansıtmaktadır (Jung, 2007). Bu nedenle öğretmenlerin etkili SY stratejilerini biliyor ve etkin biçimde kullanabiliyor olması kapsayıcı eğitim uygulamaları yapılan sınıflardaki başarıyı da arttıracaktır. Önleyici stratejiler, destek ve iletişim stratejileri, genel müdahale stratejileri ve motivasyon stratejilerini içeren bir SY her öğrencinin öğrenmesine büyük ölçüde katkı sağlayacaktır (Carneiro vd., 2015). İyi yönetilen bir sınıfta özel gereksinimi olsun ya da olmasın tüm çocukların akademik ve sosyal gelişimleri desteklenecek, problem davranışları azalacak ve olası olumsuz davranışlarının büyük bir kısmı önlenmiș olacaktır. Ayrıca öğretmenler SY stratejilerini öğrencilerin gereksinimlerine göre farklılaştırdıklarında farklı yetenek düzeylerine sahip çocuklarla daha etkili bir biçimde ilişki kurabileceklerdir (Sucuoğlu vd., 2017).

\section{Sınıf Yönetiminde Süregelen Sorunlar}

Özellikle mesleğe yeni başlayanlar olmak üzere bütün öğretmenler için önemli bir kaygı kaynağı olan SY (Dinsmore, 2003; Veenman, 1984) alanında 1950'lere kadar çok fazla gelişme yaşanmamıştır (Brophy, 2013). Öğretmen davranışı ile öğrenci davranışı arasındaki ilişki ilk defa 1970 yılında Jacop S. Kounin tarafından "Sınıflarda Disiplin ve Grup Yönetimi”" (Discipline and Group Management in Classrooms) adlı çalışmayla ortaya konmuştur. Kounin bu öncü çalışmasında önleyici yöntemlere dikkati çekerek, farkında olma, örtüşme, işaret sürekliliği ve dersin hızı, grup yönetimi ve ders anlatma tekniklerinin kullanımı gibi SY'nin temel ilkelerini ortaya koymuştur (Güner, 2011). Öğretmenlerin kullanabilecekleri etkili SY stratejileri bilimsel olarak belirlenmiş olmasına karşın günümüzde halen öğretmen adaylarının ve mesleğe yeni başlayan öğretmenlerin en çok kaygı duyduğu alanların başında SY gelmektedir (Eisenman vd., 2015). Öğretmen adayları genellikle öğretmenlik 
eğitimlerini, özellikle de SY konusunda almış oldukları eğitimlerini gelecekteki mesleki yaşamları için yetersiz olarak görmektedirler (Flower vd., 2017). Bir dizi çalışma da mesleğe yeni başlayan öğretmenlerin kendilerini yetersiz hissettikleri temel alanın SY olduğunu doğrulamaktadır (Dinsmore, 2003; Kher vd., 2000; Zuckerman, 2007). Deneyimli öğretmenler de bu konuyla ilgili benzer memnuniyetsizlikleri ifade etmektedirler (Tripp \& Seals, 2017). Yapılan araştırmalar öğretmenlerin büyük çoğunluğunun SY'yi çok önemli bir ders olarak gördüğünü buna karşın üniversitede SY ile ilgili aldıkları eğitimi yetersiz bulduklarını göstermektedir (Eisenman vd., 2015).

SY konusunda kendilerini yeterli hisseden öğretmenlerin gerçekte bu konuda ne kadar başarılı olduğu da tartışılması gereken başka bir konudur. Poulou ve diğerleri (2019) yaptıkları bir çalışmada, öğretmenlerin SY konusundaki öz yeterlik algıları ile etkili SY stratejilerini kullanma düzeyleri arasındaki ilişkiyi incelemişlerdir. Araştırma sonucunda öğretmenlerin SY alanında bildirdikleri öz yeterlik algıları ile gözlemcilerden aldıkları puanlar arasında önemli farklılıklar görülmüştür. Araştırmaya katılan öğretmenler SY stratejilerini kullanırken kendilerini verimli hissettiklerini iddia etmişlerdir. Buna karşın öğretmenlerin bu stratejileri gerçek sınıf durumlarında kullanmadıkları ya da kullanamadıkları anlaşılmıştır. Bu araştırma, öğretmenler SY konusunda kendilerini başarılı bulsalar bile gerçek durumun bundan farklı olabileceğini göstermektedir.

Gage ve diğerleri (2018) öğretmenlerin SY becerilerini uygulama oranlarının öğrencilerin öğrenme çıktılarıyla ilişkisini incelemişlerdir. Çalışmada çeşitli okul bölgelerindeki 65 ilkokuldan 1.242 öğretmen-öğrenci çifti örneğini gözlemlemişlerdir. Araştırma sonucunda SY uygulamalarını etkili biçimde kullanamayan öğretmenlerin (\%20) sınıflarındaki öğrencilerin derse katılım düzeylerinin anlamlı ölçüde düşük olduğu görülmüştür. SY stratejilerini en etkin biçimde kullanan öğretmenlerin oranı ise yalnızca \%18'dir. Buradan yola çıkarak öğretmenlerin önemli bir kısmının etkili SY stratejilerini bilmiyor ya da uygulamıyor olduğu söylenebilir.

Kapsayıcı eğitim uygulamalarına yönelik araştırmalar incelendiğinde, öğrenci çeşitliliğinin arttı̆̆ günümüz genel eğitim sınıflarında SY ile ilgili birtakım sorunlar yaşandığı anlaşılmaktadır. Gök (2013) kapsayıcı eğitim uygulamaları yapılan sınıflarda görevli sınıf öğretmenlerinin SY'de karşılaştıkları zorluklar ve bu zorluklarla başa çıkmada kullandıkları yöntemlerin belirlenmesi” amacıyla bir araştırma yürütmüştür. Araştırmada 10 sınıf öğretmeninden nitel yöntemlerle veri toplamış ve analiz edilmiştir. Elde edilen bulgular sınıfında özel gereksinimli öğrenci bulunan katılımcı öğretmenlerinin SY konusunda sorunlar yaşadığını göstermektedir. Araştırmanın katılımcıları olan öğretmenler SY konusunda yeterli eğitim almadıklarını veya aldıkları sınırlı eğitimin işe yaramadığını ifade etmişlerdir. Babaoğlan ve Yılmaz (2010) da sınıf öğretmenlerinin kaynaştırma uygulamalarına yönelik almış oldukları eğitimlerin ve öz-yeterlik algılarının belirlenmesi amacıyla bir araştırma yürütmüşlerdir. Araştırmanın tüm katılımcıları $(n=40)$ okudukları öğretmen yetiştirme programında kapsayıcı eğitim ile ilgili özel bir ders almadıklarını belirtmişlerdir. Öğretmenlerin yalnızca altı tanesi aldıkları derslerde 'kaynaştırma' konusunda içeriklerin bulunduğunu bildirmiştir. Bununla birlikte katılımcıların tamamı kaynaştırma konusunda bilgilerini yetersiz gördüklerini, 28 katılımcı ise bu konuda hiçbir bilgilerinin olmadığını ifade etmişlerdir.

Günümüz genel eğitim sınıflarındaki öğrenci çeşitliliğini arttıran bir diğer etmen de göçmen veya mülteci ailelerin sayısındaki artıştır. Kırılmaz ve Öntaş (2020) sınıf öğretmenlerinin mülteci öğrencilere yönelik kapsayıcı eğitimi gerçekleştirme düzeylerinin belirlenmesi amacıyla bir araştırma yürütmüşlerdir. Araştırmanın katılımcıları üç sınıf öğretmeni, bu öğretmenlerin sınıfında okuyan beş mülteci öğrenci ve altı Türk öğrencidir. Bu nitel araştırmanın bulguları, mülteci öğrencilerin derslere ve sosyal ortamlara yeterince katılamaması, öğretmenlerin derslerde kullanılan yöntem-teknik-ekipmanı çeşitlendirememesi ve mülteci çocukların okula devam sorunları olması gibi ciddi sorunların varlığına işaret etmektedir. Araştırma sonucunda kaynaştırma eğitimiyle bu öğrencilerin sosyal gereksinimlerinin kısmen karşılanabildiği sonucuna varılmıştır. Ünal ve Aladağ (2020), Kayseri ilinde mülteci öğrencilerin bulunduğu kaynaştırma sınıflarında çalışan 10 sınıf öğretmeninin kaynaştırma eğitimi uygulamalarına ilişkin görüşlerini incelemiştir. Araştırmanın bulguları, öğrencilerin dil sorunları nedeniyle grup etkinliklerine katılma ve kendilerini ifade etme gibi zorluklar yaşadıklarını ve öğretmenlerin doğal dili farklı olan öğrencilerle iletişim ve öğretim sorunları yaşadıklarını ortaya koymuştur. Ayrıca yazarlar, öğretmenlerin kapsayıcı eğitimle ilgili bilgi ve deneyim eksikliğini vurgulamışlardır. Mülteci öğrencilerin bulunduğu sınıflarda yapılan bu araştırmalar, artan çeşitliliğin sınıf ve davranış yönetimi sorunlarını daha da karmaşık hale getirdiğine işaret etmektedir. Alanyazındaki araştırmaların sonuçları öğretmenlerin SY konusunda yaşadığı sorunların günümüzde geçerliğini koruduğunu göstermektedir. Bu nedenle öğretmenler ve öğretmen adaylarının SY stratejileri konusunda desteklenmesi için daha etkin eğitim programlarının geliştirilmesine ihtiyaç duyulmaktadır. 


\section{Öğretmen Adaylarını Sınıf Yönetimine Hazırlama: Uygulama Eksikliği}

Ortadan kaldırılamadığında ilerleyen yıllarda öğretmen tükenmişliğinin ve iş memnuniyetsizliğinin de önemli bir nedeni olabilen SY sorunları (Evertson \& Weinstein, 2013), etkili SY stratejileri bilimsel yöntemlerle ortaya konulmuş olmasına karşın sınıfların büyük bir kısmında halen devam etmektedir. Öğretmenlerin bir kısmı özellikle sınıf içi davranışsal müdahaleler konusunda sürekli olarak ek uygulama desteği talep etmektedir (Ali vd., 2018). Bunun nedeni büyük olasılıkla öğretmen hazırlık programları sırasında bu konuda sınırlı eğitim almaları ya da SY eğitiminde kullanılan yöntemlerin etkili olamamasıdır (Tripp \& Seals, 2017; Wolff vd., 2020). Üniversite temelli öğretmen hazırlığı programları genellikle fazla teorik olduğu konusunda eleştiriler almaktadır. Birçok öğretmen yetiştirme programı ders içeriklerini ve öğretmenlik bilgi ve becerilerini teorik bir şekilde sunmaktadır (Larson vd., 2020). Aday öğretmenlere çok sayıda yaklaşımı ve yöntemi öğretip onlardan işe yarar stratejileri tahmin etmelerini ve bunları sınıflardaki gerçek durumlara genellemelerini beklemek çok gerçekçi değildir (Wolff vd., 2020). Bu nedenle, öğretmen adayları sınıfa girdiklerinde, özellikle de kendileri için zorlayıcı olan problem davranışlarla karşı karşıya kaldıklarında, öğrendiklerini uygulamakta genellikle zorlanmaktadırlar (Larson vd, 2020). Bir sınıfı yönetmenin ve SY uzmanlığını geliştirmenin karmaşıklığı, yalnızca teorik bilgi değil, aynı zamanda çeşitli sınıf durumlarıyla ilgili deneyimler de gerektirmektedir (Weber vd., 2018). Bu nedenle öğretmen yetiştirme programlarının aday öğretmenlere SY sorunlarının nasıl çözüleceğine ilişkin teorik bilgilerin yanında gerçek yaşam deneyimleri sağlaması da oldukça önemlidir (Eisenman vd., 2015). Öğretmen adaylarını teorik bilgileri edindikten hemen sonra doğrudan gerçek sınıf ortamına maruz bırakmak biraz zorlayıcı olabilir. Bu nedenle etkili SY stratejileri gibi karmaşık becerileri öğrenirken, adaylara zaman içinde karmaşıklığı artan sıralı uygulama firsatlarının sunulması yararlı olacaktır (Cohen vd., 2020). Böyle bir sıralı uygulamada teorik bilginin yanında ya da hemen ardından adayların öğrendiklerini denemeleri ve sınıf temelli senaryolarla meşgul olmaları için birtakım etkinlikler düzenlenebilir. Örneğin Eisenman ve diğerleri (2015) film çalışması, mikro öğretim, animasyonlu bir video, bir gözlem protokolü ve bir kişisel yönetim sistemi gibi uygulama etkinlikleri geliştirmişlerdir. Bu tür etkinliklerin amacı öğretmen adaylarına öğrendikleri teorik bilgileri uygulamaya dökme firsatlarının sağlanmasıdır.

Öğretmen eğitiminde kullanılan ve adaylara kendini izleme ve geri bildirim alma firsatları sağlayan bir başka uygulama da adayların temel eğitim (K-12) öğrencilerinin rolünü oynayan diğer öğretmen adaylarıyla birlikte rol ve prova yapmasıdır (Cohen vd., 2020). Rol oyunları davranış ve SY alanında öğretmen adaylarının bakış açılarını ve becerilerini geliştirmek için uzun süredir kullanılmaktadır. Rol oyunlarının yanında, öğretmen adaylarının yanıt vermesi gereken ve etkileşimli olmayan animasyon, ses, metin veya görüntüler de kullanılmaktadır (McGarr, 2020). Son yıllarda üniversite temelli öğretmen yetiştirme programlarında dijital devrimin bir parçası olarak yenilikçi teknolojilerin kullanımı da yaygınlaşmaya başlamıştır. Eğitim içerikli dijital ses dosyaları (podcast), kulaklıkta hata koçluğu (bug-in-ear technology), sanal gerçeklik (virtual reality), arttırılmış gerçeklik (augmented reality) ve karma gerçeklik (mixed-reality) gibi simülasyonlar öğretmen yetiştirme amacıyla kullanılan yenilikçi teknolojilere örnek gösterilebilir (Larson vd., 2020).

\section{Uygulama Eksikliğini Gidermede Simülasyon}

SY eğitimini yalnızca teorik bilgilendirmeden kurtarma potansiyeli olan simülasyonların kullanımı giderek yaygınlaşmaktadır. Son yirmi yılda, Arttırılmış Gerçeklik ve Sanal Gerçeklik gibi simülasyon tabanlı sanal eğitim ortamları itfaiyeci eğitimi, sağlık eğitimi ve güvenlik eğitimi gibi çeşitli alanlarda başarıyla uygulanmıştır. Simülasyonla oluşturulmuş eğitim ortamları geleneksel eğitime kıyasla birçok avantaj sağlamaktadır. Birincisi, simülasyonlar yeniden üretilmesi imkânsız, tehlikeli veya çok maliyetli olan durumlar için eğitim koşulları sağlayabilir (örneğin, uçak pilotajı, tehlikeli kimyasal kazalara müdahale); ikincisi, sanal ortamlarda yapılan hataların gerçekliği etkilemediği ve kullanıcıların hedeflere ulaşana kadar eğitimi tekrar etmelerine izin veren bir sanal ortam oluşturması; üçüncüsü, kullanıcıları müdahale yapmalarını gerektiren durumlara maruz bırakarak uygulamalı deneyimler sağlayan aktif öğrenmeyi desteklemesidir (Delamarre vd., 2019). Araştırmalar simülasyonların rol yapma veya provalar gibi diğer yaklaşımlardan daha gerçekçi hissettirdiğini ve simülatörde eğitim alan kişilerin kendilerinden beklenilen davranışlara daha yakın tepkiler verdiğini göstermektedir. Öğretmen eğitiminde simülasyonlar gerçek sınıf deneyimi öncesi aşamada sunulabilir ve böylece adaylara daha standartlaştırılmış ve daha az karmaşık ortamlarda becerilerini geliştirme fırsatı sağlanmış olur. Simülatörler sayesinde bu beceriler zamanla güçlendirilir ve adaylar gerçek sınıf deneyimleri sırasında karşılaşabileceği senaryolar konusunda uzmanlaşabilir (Cohen vd., 2020).

İnsan sosyal davranışını taklit edebilen sanal öğrencilerden oluşan sanal sınıflar sosyal becerileri geliştirmek üzere tasarlanmış etkileşimli simülasyon ortamları oluşturmayı mümkün kılmaktadır. Bu tür sanal 
ortamlar kullanılarak öğretmen adaylarının yüksek stresli durumlarda iletişim becerilerini geliştirebileceği ve sanal öğrencilerin problem davranışlarına kontrollü bir şekilde maruz kalabileceği senaryolar geliştirilebilmektedir (Delamarre vd., 2019). Lugrin ve diğerleri (2016) oluşturdukları sanal sınıf ile öğretmen adaylarına bilgilerini sınama ve geliştirme ortamı hazırlamışlardır. Sanal gerçeklik ile oluşturulan bu ortamdaki sanal öğrenciler tam otomatik (otonom) veya online işlem (teleoperasyon) yoluyla başka bir kullanıcı tarafindan uzaktan kontrol edilebilmekte ve bu sayede kontrollü bir biçimde istenilen türde sınıf ve öğrenci davranışları oluşturulabilmektedir. Giyilebilir sanal gerçeklik başlığı sayesinde öğretmen adayı kendisini bu sanal sınıfın içerisinde görmekte ve sınıfta belirli bir alan içinde serbestçe dolaşabilmektedir. Benzer bir çalışmada Mahon ve diğerleri (2010) sosyal paylaşım için oluşturulmuş bir web aracı olan "Second Life" kullanarak sanal bir sınıf oluşturmuştur. Bu araştırmaya katılan öğretmen adayları, sanal sınıf ortamının mesleki gelişimlerine faydalı olacağını düşündüklerini ifade etmişlerdir.

Öğretmen adayları etkili SY stratejilerini gerektiği şekilde kullanmak, SY konusunda alacağı kararların öğrenciler üzerindeki etkilerini tahmin etmek ve geliştirilmesi gereken yönlerini belirlemek konusunda yeterli bilgiye sahip olmayabilir. Bu nedenle simülasyon ortamları ile hazırlanan etkinliklerde öğretmen adaylarına uzman eğitimciler tarafından geri bildirimler sağlanması oldukça önemlidir. Bir uzman eğitimci, simülasyonu kullanan öğretmen adaylarının güçlü ve zayıf yönleri, öğrenci çıktıları üzerindeki öğretimsel seçimlerinin olası etkileri ve iyileştirme stratejileri hakkında görüşler sunarak uzmanlık geliştirmelerine yardımcı olmalıdır (Cohen vd., 2020). Pas ve diğerleri (2019), davranış yönetimi becerilerini geliştirerek öğretmenlerin okullarda akran zorbalığıyla başa çıkmalarına yardımcı olmak için 4 aylık bir program uygulamışlardır. Program süresince öğretmenlere, öğrencilerin zorbalık davranışlarını tespit etme, önleme ve bunlara tepki verme ile ilgili stratejiler hakkında uzman eğitimci desteği (UED) ve simülatör uygulamasını içeren bir koçluk modeli ile eğitim verilmiştir. Kontrol gruplu deneysel desenle yürütülen bu araştırmanın katılımcıları 78 ortaokul öğretmenidir. Araştırma sonucunda UED ve simülatör ile eğitim alan öğretmenlerin almayanlara oranla akran zorbalığı ile baş etmede daha başarılı oldukları görülmüştür. Göreve yeni başlayan öğretmenler ve öğretmen adayları SY becerilerinin geliştirilebilmesi için gerçek sınıflarda görev almadan önce öğrencilerin problem davranışları ile baş etme konusunda daha çok uygulama firsatlarına ihtiyaç duymaktadır. UED içeren simülasyonlar sayesinde başta SY olmak üzere çeşitli stratejilerin öğretiminde uygulama firsatlarının oluşturulmasına yönelik etkin çözümler üretilebilmektedir (Pas vd., 2019).

\section{Görevdeki Öğretmenler için Sınıf Yönetimi Eğitimi}

Sınıflarda bireysel farklılıkların giderek çeşitlendiği ve sayıca arttığı düşünüldüğünde göreve başlayan öğretmenlerin - ve elbette deneyimli öğretmenlerin - yüksek öncelikli gereksinimlerinden biri etkili SY stratejileri konusunda destek almaktır. Dünyanın pek çok yerinde öğretmen mesleki gelişimi için yaygın olarak kullanılan bir uygulama hizmet içi eğitim olarak da adlandırılan atölye çalışmalarıdır. Geleneksel atölye çalışmaları öğretmenlere yeni teknikler hakkında bilgi vermek ve fiilen uygulamadan önce daha derin bir anlayış geliştirmek için daha fazla zaman sağlaması bakımından yararlıdır. Ancak her yıl yüksek miktarda emek, zaman ve para harcanan bu tür uygulamaların öğretmen tutum ve davranışları veya sınıfın öğrenme çıtılları üzerinde istendik değişikliği yapabildiğine yönelik yeterli kanıt bulunmamaktadır (Cilliers vd., 2020). Bir başka ifadeyle atölye çalışmaları gibi daha geleneksel eğitim biçimleri, sınıflarının kültürünü geliştirmek isteyen ve buna gereksinim duyan öğretmenler için yeterli desteği sağlayamamaktadır (Reinke vd., 2008). Amerika Birleşik Devletleri'ndeki pek çok çalışma, bu türden mesleki gelişim programlarının, özellikle hükümet tarafından geniş ölçekte yürütüldüğünde, öğrenci öğrenimi üzerinde hiçbir etkisi olmadığı görüşünü desteklemektedir (Cilliers vd., 2020). Ülkemizde yapılan iki çalışmada da benzer bulgulara rastlanmıştır. Bu çalışmalardan ilkinde Güner (2011), genel eğitim okullarında kaynaştırma uygulaması yapılan sınıflarda çalışan öğretmenlerin SY becerilerinin geliştirilmesi amacıyla hizmet içi eğitime benzer bir eğitim program uygulamıştır. Elde edilen bulgulara göre uygulanan geleneksel öğretim programı öğretmenlerin SY konusundaki teorik bilgi düzeylerini artırırken, sınıf içinde öğretim sürecinde SY stratejilerini kullanma düzeylerinde anlamlı bir değişikliğe yol açmamıştır. İkinci çalışmada ise Sucuoğlu ve diğerleri (2015), kaynaştırma ile ilgili konuları ve kapsayıcı sınıflar için etkili stratejileri içeren bir öğretmen eğitimi programı uygulamışlardır. Bu araştırmanın sonucunda, uygulanan programın öğretmenlerin bilgi düzeylerinde orta-büyük bir etkiye sahip olmasına karşın sınıfdaki öğretmen davranışları üzerindeki etkisinin oldukça düşük olduğu görülmüştür. Ertürk (2019) de, Türkiye'de hizmet içi eğitimin etkililiği ile ilgili sorunların Millî Eğitim Bakanlığı tarafından da bildirildiğini ancak bugüne kadar somut bir gelişme sağlanamadığını vurgulamaktadır. 


\section{Teori ve Pratiği Birleştiren Eğitimler: Uzman Eğitimci Desteği}

Yapılan araştırmalar öğretmen mesleki gelişim programlarının en yaygın biçimi olan tek seferlik geleneksel atölye çalışmalarının büyük ölçüde etkisiz olduğunu ve genellikle sınırlı beceri aktarımına ve zayıf öğrenme çıktılarına yol açtığını göstermektedir. Atölye tarzı modellerin başarısızlı̆̆ı "uygulama ile meşgul olma" ve "uygulama sırasında destek alma" gibi iki kritik bileşenin eksikliğinden kaynaklanmaktadır. Birçok geleneksel model yalnızca bilgi aktarmaya odaklanmaktadır (Cilliers vd., 2020). Oysa öğretmenlere etkili bir mesleki gelişim firsatı sunulabilmesi için bunun zaman içinde gerçekleşmesi ve süreç boyunca kendilerine gereken desteğin sağlanması gerekir. Gereken rehberlik ve desteğin sağlanmaması durumunda becerilerinin ustalığa dönüşebilmesi için önemli ölçüde zaman ve pratik gerekmektedir. Araştırmalar ilk uygulama aşamalarında gözlem, uygulama ve performans geri bildirimi gibi desteklerin sağlanmasının öğretmenlerin yeni becerilere hâkim olmasını kolaylaştırabileceğini ve hızlandırabileceğini göstermektedir (Akalın \& Sucuoğlu, 2015; Reinke vd., 2008; Timuçin, 2008). Çünkü insanlara davranış değişikliği hakkında düşünme ve karar verme firsatı verildiğinde daha başarılı oldukları bilinmektedir. Bu nedenle öğretmen mesleki gelişimine öğrenci çalışmalarıyla doğrudan meşgul olabilecekleri, öğretimleri hakkında doğrudan geri bildirim alabilecekleri veya kendi sınıflarındaki uygulamalarını gözden geçirebilecekleri dinamik ve aktif bir süreç olarak yaklaşıllmalıdır (Reinke vd., 2008). Başka bir ifadeyle öğretmen mesleki gelişim programlarında teori ve pratik bilgiler harmanlanarak sunulmalıdır (Emmer \& Stough, 2001).

Teori ve pratik bilgileri birleştirmek ve öğretmenlere yararlı geri bildirim sağlamak için koçluk ve mentorluk uygulamaları gün geçtikçe yaygınlaşmaktadır. UED sağlamaya yönelik bu tür uygulamalar sınıf temelli pratik yapmaya olanak sağlamaları nedeniyle "uygulama ile meşgul olma" ve "uygulama sırasında destek alma" konularındaki boşluğu doldurabilirler (Pas vd., 2016). Pek çok araştırmanın bulguları öğretmenlerin sınıftaki uygulamalarını iyileştirebilmek için etkili bir yöntem olarak UED'yi desteklemektedir (Akalın \& Sucuoğlu, 2015; Ennis vd., 2020; Timuçin, 2008). Kraft ve diğerleri (2018) tarafindan yapılan bir meta-analiz çalışmasında UED hakkındaki 44 araştırmanın etkileri incelenmiş ve UED'nin ölçülen öğretmen davranışları ve öğrenci başarısı üzerinde büyük etkisi olduğu sonucuna ulaşılmıştır (Cohen vd., 2020). Güner-Yıldız ve Kurtova (2017) bireysel gereksinimlerinin farklılığı nedeniyle uyum güçlükleri yaşayan öğrencilerin problem kaynağı olarak görüldükleri kaynaştırma eğitimi uygulanan bir ilkokul birinci sınıftaki davranış ve öğrenme sorunlarına çözüm üretmek amacıyla bir UED programı uygulamışlardır. Araştırmada elde edilen bulgular, sınıf öğretmeninin aldığı bireysel danışmanlık ve destek sonucunda, problem davranışları önleme, öğrencilerin istendik davranışlarını arttırmada ödül kullanımı, öğrencilerin davranışlarına karşı tutarlı tepkiler verme ve sınıftaki özel gereksinimli öğrencilerin bireysel farkl1lıklarına uygun öğretim düzenlemeleri yapma konularında sınıf düzenini olumlu yönde etkileyen davranış değişikliği gösterdiğini ortaya koymuştur. İki farklı çalışmada, bir eğitim programı uygulandıktan sonra öğretmenlere performans geri bildirimi ile uzman desteği sağlanmıştır. Bu çalışmalardan ilkinde Akalın ve Sucuoğlu (2015), sınıf yönetimi stratejileri üzerine eğitim verildikten sonra günlük performans geri bildirimlerinin öğretmen ve öğrenci çıktıları üzerindeki etkisini incelemiştir. Araştırma sonuçları, öğretmenlerin önleyici sınıf yönetimi becerileri ile öğrencilerin akademik katılımlarının arttı̆̆ını göstermiştir. İkinci çalışmada ise İşcenKarasu (2017) kaynaştırma uygulaması yapılan okul öncesi sınıflarında çalışan öğretmenlere önleyici sınıf yönetimi stratejileri konusunda eğitim vermiş ve ardından hedef stratejilere ilişkin performans geribildirimi sağlamıştır. Bu araştırmanın bulguları, öğretmenlere bireysel olarak ve hedef davranışlarında bağımsız hale gelinceye kadar verilen uzman eğitimci dönütlerinin hem öğretmen davranışları hem de öğrencilerin öğrenme çıktıları üzerinde olumlu değişimlere neden olduğunu göstermiştir.

Başka bir araştırmada Güney Afrika Cumhuriyeti’ndeki 180 ilköğretim okulunun öğretmenleri için iki hizmet içi mesleki gelişim yaklaşımı deneysel olarak karşılaştıılmıştır. Birinci yaklaşım birçok hükümet tarafından kullanılan geleneksel hizmet içi eğitim modeli (merkezi bir mekânda düzenlenen kısa, yoğun eğitim), ikinci yaklaşım ise uzman eğitimcilerin öğretim uygulamalarını gözlemlemek ve geri bildirim sağlamak için öğretmenleri aylık olarak ziyaret ettiği koçluktur. Sonuç olarak koçluğun, öğrenci okuma yeterliliği üzerinde geleneksel hizmet içi eğitimin iki katından fazla ve istatistiksel olarak anlamlı bir etkisi olduğu görülmüştür (Cilliers vd., 2020). Bilimsel kanıtların birikmesiyle birlikte hizmet içi mesleki gelişim alanı, UED’nin öğretmen mesleki gelişimini desteklemenin en etkili yollarından biri olduğu fikri etrafında birleşmektedir (Cohen vd., 2020). Buna paralel olarak da UED öğretmen etkinliğini artırmak ve öğretmenlerin profesyonel gelişimini desteklemek için giderek daha popüler bir yöntem haline gelmektedir (Ennis vd., 2020).

Alanyazında gördüğümüz UED modelleri odak ve etkinlik açısından farklılıklar göstermektedir. Bununla birlikte mevcut programlar genellikle işe yerleştirilmiş uygulama, yoğun ve uzun süreli iş birliği gibi birçok kritik özelliği paylaşmaktadır (Desimone \& Pak, 2017). Geleneksel atölye modelinin aksine UED modelleri öğretmen 
beceri gelişimini kolaylaştırmak için aktif öğrenme yaklaşımlarının bileşenlerini (örneğin, modelleme, uygulama ve geri bildirim) barındırmaktadır. Çoğu UED programında, uzman eğitimcilerin gözlemlenen öğretmen gereksinimlerine yanıt vermesi, öğretmenleri uygulamalarını eleştirel bir şekilde değerlendirmeye sevk etmesi ve bazı durumlarda gelişimlerini desteklemek için daha yönlendirici geri bildirimler sağlaması gerektiği vurgulanmaktadır (Cohen vd., 2020). UED döngüleri tipik olarak sınıf gözlemlerinden ve ardından öğretmenlerin uygulamaları hakkında hedeflenen geri bildirimlerden ve iyileştirme için özel önerilerden oluşur. Bu döngüler, tam bir akademik yıl veya daha uzun bir süre boyunca meydana gelebilir ve uzman eğitimciler öğretmenlerle bire bir veya küçük gruplar halinde çalışarak kişiselleştirilmiş geri bildirimler sağlayabilir (Kraft vd., 2018). Uzman eğitimci olarak hizmet verecek personelin birtakım becerilere ve yetkinliklere sahip olması gerektiği unutulmamalıdır. Uzman eğitimcilerin veri toplama, hedef belirleme, planlama ve zaman yönetimi, etkili mesleki gelişim programları tasarlama ve sunma, iletişim ve problem çözme gibi becerilerin yanında güven oluşturma, gizlilik ve mesleki etik ile ilgili konularda da yetkin olması beklenmektedir (Denton \& Hasbrouck, 2009).

\section{Tartıșma}

\section{Eğitim Vizyonu Çerçevesinde Çözüm için Öneriler}

SY konusunda var olan temel sorunlar öğretmen yetiştirme programlarında uygulama eksikliği, göreve yeni başlayan öğretmenlere yeterli destek sağlanamaması ve görevdeki öğretmenlerin mesleki gelişimlerinin etkin biçimde sürdürülememesidir. Ayrıca okulların her geçen gün daha fazla kapsayıcı olması SY'de öğretmen hazırlı̆̆ ve gelişimini sağlamada yeni ve etkili stratejilerin kullanımını da zorunlu kılmaktadır. Her bir öğretmen adayı farklı bireysel özellikleri olan çocuklardan oluşan sınıflarda etkili SY uygulamaları yapabilecek ve öğrencilerinin başarısını sağlayacak yöntemleri kullanabilecek yeterliğe ulaştıktan sonra eğitim fakültelerinden mezun olmalıdır. Halen görevde olan öğretmenlerin de kapsayıcı eğitim çerçevesinde yeniden gelişimlerinin sağlanması ve etkili SY stratejilerini kullanmayı öğrenmeleri gerekmektedir. Ulusal bir plan çerçevesinde öğretmen adaylarıyla birlikte görevi başındaki öğretmenlerin SY konusundaki gelişimini sağlayacak adımlar atılması hem kapsayıcı eğitimin hem de öğretmen ve öğrencilerin başarısı için önemlidir.

Milli Eğitim Bakanlığı (MEB), eğitim sisteminin aksayan yönlerinin belirlenmesi ve var olan sorunlara köklü çözümler üretilebilmesi için birtakım çalışmalar yapmaktadır. Bu çalışmalardan biri 2018 yılında yayınlanan "2023 Eğitim Vizyonu" belgesidir (MEB, 2020). Bu belge eğitim sisteminde yapılması planlanan değişim ve dönüşümlerin, ana hatlarıyla da olsa, bir yol haritasını içermesi nedeniyle önemli bir gelişme olarak kabul edilmektedir. Vizyon belgesinde ele alınan önemli konulardan biri de insan kaynaklarının geliştirilmesi ve yönetilmesidir (Elçiçek \& Han, 2018). 2023 Eğitim Vizyonu bu konuyla ilgili olarak "İhtiyaç duyulan ölçütleri taşıyan eğitim fakültelerinde, özgün bir yapılanmayla uygulama ağırlıklı öğretmen yetiştirme programları düzenlenecektir." ifadesini içermektedir (MEB, 2020). Bu ifadeden anlaşılacağı üzere bazı öğretmen yetiştirme programlarında bir dönüşüm yapılacağı ve bu dönüşümde uygulamaya daha çok ağırlık verileceği planlanmaktadır (Ertürk, 2019). Bu olumlu gelişme sayesinde öğretmen adayları edindikleri teorik bilgileri pratiğe yansıtma konusunda daha çok firsat bulacaklardır. Bu noktada, öğretmen adaylarına uygulama firsatları oluşturmada alanyazındaki bulguların ışığında dikkate alınması gereken hususlar bulunmaktadır.

\section{Aday Öğretmenler için Uygulamalı Sınıf Yönetimi Eğitimi}

Aday öğretmenlerin teorik eğitimleri ile gerçek sınıflarda öğrencilerle yüz yüze okul uygulamaları yapmaları arasında ara basamakların olması gerekmektedir (Cohen vd., 2020). Böylece öğretmen adayları gerçek sınıf olaylarına doğrudan maruz kalmak yerine kademeli bir geçiş yapabilmiş olacaklardır. Alanyazında aday öğretmenlere SY'de uygulama şansı sağlamayı amaçlayan çeşitli çalışmalara rastlanmaktadır. Örneğin bir araştırmada (Siebert, 2005), Okul Profesyonel Gelişim Girişimi adlı bir oluşumun, üniversitede eğitimleri sırasında yeterince uygulama yapma şansı bulamayan öğretmen adaylarına etkili SY stratejilerini sınıflarda kullanma şansı sağladığı ele alınmaktadır. Eisenman ve diğerleri (2015) ise film çalışması, mikro öğretim, animasyonlu bir video, bir gözlem protokolü ve bir kişisel yönetim sistemi gibi uygulama etkinlikleri geliştirerek aday öğretmenlerin SY'de eğitiminde teori ve uygulamayı birleştirmeyi amaçlamışlardır. Ayrıca teori ve uygulamayı birleştirmede teknolojiden de yararlanılabilir. Simülasyon bu konuda etkili çözümler üretebilme potansiyeli olan teknolojilerden biridir. Ülkemizde simülasyon teknolojilerinin potansiyelinden yararlanma adına özellikle havacılık ve güvenlik birimlerimizin eğitimi alanlarında geliştirilmiş veya geliştirilmekte olan ulusal ölçekli projelerin olduğu bilinmektedir (Hava Elektronik Sanayi [HAVELSAN], 2020; Orta Doğu Teknik Üniversitesi [ODTÜ], 2020). Simülasyonlar sayesinde güvenlik birimlerimiz ve pilotlarımız gerçek durumlara maruz kalmadan önce öğrendikleri teorik bilgiyi uygulamaya dökme firsatı bulabilmektedir (Özmen \& Denktaş, 2011). Ulusal düzeyde benzer bir çalışma da eğitim alanında yürütülerek öğretmen yetiştirme amaciyla 
kullanılacak simülasyonlar geliştirilebilir. Kalabalık bir sınıf ortamında, otonom ve tele-operasyon yoluyla hareketlendirilebilen ve sosyal davranışlar sergileyebilen sanal öğrencileri içeren nitelikli bir simülatörün geliştirilebilmesi için öncelikle MEB ve Yükseköğretim Kurulu (YÖK) iş birliğinde gereksinimler belirlenmeli ve uygun bir model tasarlanmalıdır. Üniversiteler ve simülasyon teknolojileri konusunda yeterliliği olan kurum ve kuruluşlarla birlikte çalışılarak ulusal ölçekli bir proje ile öğretmen yetiştirme programlarında kullanılacak simülatör ya da simülatörler geliştirilmesi yararlı olacaktır. Simülasyon teknolojileri ya da başka araçlarla oluşturulmuş uygulama etkinliklerinde öğretmen adaylarına UED verilmesi ve böylece yakından izlenen bir uygulama süreci, yapıcı geri bildirimler ve uzman eğitimcilerin yardımıyla kendi performansları üzerinde düşünmelerine olanak sağlanması sonucunda yapılan öğretimin niteliğini daha da arttırılacaktır (Reinke vd., 2008). $\mathrm{Bu}$ sayede öğretmen adayları gerçek öğrencileriyle yüz yüze uygulama aşamasına daha donanımlı bir biçimde geçebileceklerdir.

Aday öğretmenlerin gerçek sınıflarda çalışmaya hazırlanmasında MEB'e bağlı okullarda yaptıkları öğretmenlik uygulamasının da önemi büyüktür. Bu uygulama "öğretmen adaylarının öğretmenlik mesleğine daha iyi hazırlanmalarını; öğrenimleri sırasında edindikleri bilgi, beceri, tutum ve davranışlarla genel kültür ve özel alan eğitimlerini gerçek bir sınıf ortamında kullanma yeterliğine sahip olarak yetiştirilmelerini” amaçlamaktadır (MEB, 2018). Öğretmenlik uygulamasına ilişkin yapılan bir araştırmada (Ekinci vd., 2019) 207 aday öğretmen ve aday öğretmenlere danışmanlık yapmakla görevlendirilen 179 uygulama öğretmeninin öğretmenlik uygulamalarıyla ilgili görüşleri incelenmiş̧tir. Araştırmanın öne çıkan bulguları arasında "mesleki gelişim ve eğitim tecrübelerinin paylaşılmasının önemi" ve "uygulanan programının aday öğretmenlere yönelik olarak hedeflenen yeterlikleri kazandırmadığı ve amaca ulaşmadığı" yer almaktadır. Araştırmacıların sorunun çözümüne yönelik olarak sunduğu; uygulama öğretmenliğinin şartlarının iyileştirilmesi ve cazip hale getirilmesi ile "uygulama öğretmenlerinde yeterlik aranmalı" önerileri oldukça önemlidir.

Aday öğretmenler için yüz yüze öğretmenlik uygulamaları düzenlenirken dikkat edilmesi gereken bir konu uygulama sürecinde kendilerine destek sağlayacak uzman eğitimcilerin belirlenmesi ve yetiştirilmesi ile ilgilidir. 2018'de yayınlanan Öğretmenlik Uygulama Yönergesi gereğince öğretmen adaylarına rehberlik edecek uygulama öğretmenleri için "Millî Eğitim Bakanlığı tarafından verilen Öğretmenlik Uygulaması Eğitimi Sertifikasına sahip olma" şartı aranmaktadır (MEB, 2018). Bu ifadeden de anlaşılacağı üzere 2018 yılı itibariyle öğretmenlik uygulamalarında görevlendirilecek öğretmenler için sertifika alma koşulu getirilmiştir. Ancak öğretmenler bu sertifikayı kısa süreli bir geleneksel atölye çalışmasıyla alabilirler. Oysa bu sertifikanın nasıl verildiği önemsenmesi gereken bir konudur. Çünkü bir tür UED olan bu uygulamaların istenilen hedeflere ulaşabilmesi için uzman eğitimci olarak görev yapan uygulama öğretmenlerinin yeterlikleri kritik öneme sahiptir. Çünkü meslekte deneyimli olmak, atölye tarzı hizmet içi eğitim sertifikası sahibi olmak ya da kendini yeterli hissetmek aynı zamanda yetkin olmak anlamı taşımayabilmektedir (Ekinci vd., 2019; Poulou vd., 2019). Bu nedenle UED verecek uygulama öğretmenlerinin mesleki anlamda, özellikle de SY konusunda başarılı olanlar arasından seçilmesi yapılan uygulamanın niteliğini de arttıracaktır.

Öğretmenlik Uygulama Yönergesinde bununla ilgili olarak "öğretmenlik uygulamalarına katılan personelin yeterlikleri ve uygulama süreci değerlendirilir ve sürekli geliştirilir" ifadesi yer almaktadır (MEB, 2018). Bu ifade gereğince öğretmen adaylarına rehberlik edecek uzman eğitimcilerin/uygulama öğretmenlerinin yeterliklerinin geliştirilmesi için süreç içerisinde hem SY hem de UED konularında mesleki gelişimlerine yönelik çalışmalar yürütülmelidir. Böylece aday öğretmenlere sağlanan uygulama fırsatının niteliği artacak ve uygulama öğretmenlerinin mesleki başarısı da zamanla yükselmiş olacaktır.

\section{Görev Başındaki Öğretmenler için Sınıf Yönetimi Eğitimi}

Yalnızca aday öğretmenlerin değil görevi başındaki öğretmenlerin mesleki gelişimi de önemsenmesi gereken bir konudur. 2023 Eğitim Vizyonu bu konuda da birtakım gelişmelerin hedeflendiğine işaret etmektedir (MEB, 2020). Vizyon belgesinde şu ifadeler yer almaktadır:

1. Öğretmen ve okul yöneticilerimize yönelik bazı hizmet içi eğitim faaliyetleri, katılıma ilişkin belgelendirme uygulamasından ayrılarak üniversiteler aracılığılla akredite sertifika programlarına dönüştürülecektir.

2. Öğretmenlerin mesleki gelişimi, lisansüstü düzeyde desteklenecektir.

Öğretmenlerin mesleki gelişimini destekleme konusunda üniversitelerle iş birliği yapılacağı vurgusu olumlu bir gelişmedir. Ancak vizyon belgesi okul temelli mesleki gelişim konusunda çalışmalar yapılacağıyla ilgili açık bir bilgi içermemektedir (Elçiçek \& Han, 2018). Okul temelli çalışmalarla öğretmenlerin SY 
konusundaki yeterliklerinin geliştirilmesi etkili bir öğretmen eğitimi için önemlidir (Korb vd., 2016). YÖK iş birliğinde gerçekleştirilecek üniversite temelli sertifika programlarının yanında SY konusunda başarılı öğretmenlerin UED konusunda eğitilmesi ve diğer meslektaşlarına destek sağlaması, gereksinimi olan öğretmenlerin mesleki gelişimini arttırması bakımından yararlı olacaktır. Bunun için öncelikle öğretmenlerin SY konusundaki yeterlikleri nesnel yöntemlere ölçülmeli ve yapılan değerlendirme sonucunda gereksinimler belirlenmelidir. Yapılan nesnel değerlendirmeler sonucunda bilgi ve beceri eksikliği olduğu belirlenen öğretmenlere küçük grup ya da bireysel UED sağlanarak mesleki gelişimleri sürekli olarak desteklenmelidir. UED uygulamalarının başarısını artırmak için meslektaşlarına uzman eğitimci olarak destek sağlayacak deneyimli öğretmenler öğretim ve SY konularındaki yeterlikleri bakımından objektif kriterlere göre belirlenmelidir. Ayrıca bu başarılı öğretmenlerin mesleki gelişimleri de daha iyi uzman eğitimciler olabilmeleri için desteklenmelidir.

Genel olarak öğretmenlik mesleğinin başarısını artırmak için, tüm öğretmenlerin mesleki gelişimi teşvik edilmeli ve desteklenmelidir. Ayrıca deneyimli ve başarılı öğretmenlerin uzman eğitimci olma yolunda mesleki gelişimleri desteklenmeli ve uzman eğitimci olamak cazip hale getirilmelidir. Cazip hale getirmek için başarılı öğretmenlere okullar arası yer değiştirme, yönetici atamaları ve maaş konularında birtakım avantajlar sağlanabilir. Ayrıca MEB'in yakın zamanda hayata geçirmeyi planladığı öğretmen kariyer basamakları sistemi (MEB, 2020) bu amaçla kullanılabilecek bir araç olabilir. Çünkü kariyer basamakları öğretmenlerin mesleki gelişimini destekleyen ve teşvik eden bir sistem olarak görülmektedir (Bakioğlu \& Banoğlu, 2013). Vizyon belgesinde kariyer basamaklarıyla ilgili olarak "Öğretmen ve okul yöneticilerimiz için Yatay ve Dikey Kariyer Uzmanlık Alanları yapılandırılacaktır" ve "Yatay ve dikey kariyer basamaklarına yönelik lisansüstü düzeyde mesleki uzmanlık programları açılacaktır." ifadeleri yer almaktadır. Kariyer basamakları sisteminde lisansüstü öğrenim programlarının yanında okul temelli mesleki gelişim programlarının da kullanılması uygulamalı eğitim içermesi nedeniyle öğretmenlerin SY konusundaki gelişimlerini daha fazla destekleme potansiyeline sahiptir. Görevdeki öğretmenlerin SY becerileri nesnel yöntemlerle ölçülerek kariyer basamaklarında ilerleme ölçütü haline getirilmeli ve böylelikle kariyer basamakları sisteminin mesleki gelişim konusunda öğretmenlere bir motivasyon kaynağı olması sağlanmalıdır.

Özetle, SY konusunda yetkin öğretmenler yetiştirirken dört önemli nokta göz ardı edilmemelidir. Birincisi, öğretmen adaylarını kaynaştırma sınıflarında çalışmaya ve öğrencilerin öğrenme ve davranış özelliklerine göre yöntem ve stratejilerini farklılaştırabilmeye odaklanmaları başka bir ifade ile kapsayıcı sınıflarda çalışmaya hazırlanmaları gerekliliğidir. Bunun için SY eğitiminin kaynaştırma sınıflarında öğrenme ve davranış problemlerine cevap verebilecek ve öğretmen adaylarına çeşitli seviyelerde uygulama firsatları sağlayacak stratejileri (geri bildirim, rol yapma, simülasyon kullanımı, danışmanlık, koçluk veya mentorluk vb.) içerecek şekilde planlanması önerilmektedir. İkincisi, teorik bilgiyi yoğun ve kısa süreli geleneksel atölye çalışmalarıyla sağlamak yerine öğretmen mesleki gelişimi için okul temelli uygulamaları içeren yöntemlerin kullanılması gerekmektedir. Özellikle kaynaştırma uygulamaları yapılan sınıflarında çalışan öğretmenlerin destek ihtiyaçlarının belirlenmesi ve ihtiyaçları doğrultusunda EUD sağlanması gerekmektedir. Üçüncüsü, uzman eğitimci olarak atanacak öğretmenler, SY'deki mesleki başarıları ve yeterlilikleri açısından objektif kriterlere göre belirlenmelidir. Ayrıca, uzman eğitimcilerin de mesleki gelişimleri kariyerleri boyunca desteklenmelidir. Dördüncüsü, tüm öğretmenler mesleki gelişimlerinde teşvik edilmelidir. Bu amaçla öğretmenlik kariyer basamakları sistemi daha etkin kullanılmalıdır. Bununla birlikte, yapılacak iyileştirme çalışmaların başlangıç noktası tüm paydaşların SY'nin önemi konusundaki farkındalığını artırmak olmalıdır. SY'nin öğretmen niteliği ve öğrencilerin akademik başarısı için büyük önem taşımasına rağmen eğitim camiasında yeterince ele alınmayan bir alan olduğu bilinmektedir (Evertson \& Weinstein, 2013). Bu nedenle, SY çalışmalarına yönelik ilgiyi artırmak için, eğitim fakültelerinde ve öğretmen istihdam eden kurumlarda SY'nin öğrenci davranışları ve başarısı üzerindeki etkisini ortaya koyan çalışmaların bulgularına ilişkin bilgilendirici çalışmalar yürütülmelidir.

\section{Yazarların Katkı Düzeyleri}

$\mathrm{Bu}$ çalışmanın fikir, tasarım ve eleştirel inceleme işlemleri birinci yazar Nevin Güner-Yıldız tarafindan yürütülmüştür. Çalışmanın literatür taraması aşaması Hasan Köse ve Esra Akın tarafından gerçekleştirilmiştir. Yazım aşamasında her üç yazar da görev almışlardır. Esra Akın ve Hasan Köse, çalışmanın dergi yazım kurallarına göre düzenlenmesi işlemlerini yürütmüşlerdir. 